\title{
PARP1 protects from benzo[a]pyrene diol epoxide-induced replication stress and mutagenicity
}

\author{
Jan M. F. Fischer ${ }^{1,2} \cdot$ Tabea Zubel $^{1,2} \cdot$ Kirsten Jander $^{1} \cdot$ Jelena Fix $^{1} \cdot$ Irmela R. E. A. Trussina $^{1} \cdot$ Daniel Gebhard $^{3}$. \\ Jörg Bergemann ${ }^{3} \cdot$ Alexander Bürkle $^{1} \cdot$ Aswin Mangerich $^{1}$
}

Received: 24 September 2017 / Accepted: 8 November 2017 / Published online: 1 December 2017

(c) The Author(s) 2017. This article is an open access publication

\begin{abstract}
Poly(ADP-ribosyl)ation (PARylation) is a complex and reversible posttranslational modification catalyzed by poly(ADPribose)polymerases (PARPs), which orchestrates protein function and subcellular localization. The function of PARP1 in genotoxic stress response upon induction of oxidative DNA lesions and strand breaks is firmly established, but its role in the response to chemical-induced, bulky DNA adducts is understood incompletely. To address the role of PARP1 in the response to bulky DNA adducts, we treated human cancer cells with benzo[a]pyrene 7,8-dihydrodiol-9,10-epoxide (BPDE), which represents the active metabolite of the environmental carcinogen benzo[a]pyrene $[\mathrm{B}(\mathrm{a}) \mathrm{P}]$, in nanomolar to low micromolar concentrations. Using a highly sensitive LC-MS/MS method, we revealed that BPDE induces cellular PAR formation in a time- and dose-dependent manner. Consistently, PARP1 activity significantly contributed to BPDE-induced genotoxic stress response. On one hand, PARP1 ablation rescued BPDE-induced $\mathrm{NAD}^{+}$depletion and protected cells from BPDE-induced short-term toxicity. On the other hand, strong sensitization effects of PARP inhibition and PARP1 ablation were observed in long-term clonogenic survival assays. Furthermore, PARP1 ablation significantly affected BPDE-induced S- and G2-phase transitions. Together, these results point towards unresolved BPDE-DNA lesions triggering replicative stress. In line with this, BPDE exposure resulted in enhanced formation and persistence of DNA double-strand breaks in PARP1-deficient cells as evaluated by microscopic co-localization studies of 53BP1 and $\gamma \mathrm{H} 2 \mathrm{~A}$.X foci. Consistently, an HPRT mutation assay revealed that PARP inhibition potentiated the mutagenicity of BPDE. In conclusion, this study demonstrates a profound role of PARylation in BPDE-induced genotoxic stress response with significant functional consequences and potential relevance with regard to $\mathrm{B}[\mathrm{a}] \mathrm{P}-\mathrm{induced}$ cancer risks.
\end{abstract}

Keywords PARP $1 \cdot$ Poly(ADP-ribosyl)ation $\cdot$ Benzo[a]pyrene $\cdot$ BPDE $\cdot$ Replication stress

Jan M. F. Fischer and Tabea Zubel shared first authorship.

Electronic supplementary material The online version of this article (https://doi.org/10.1007/s00204-017-2115-6) contains supplementary material, which is available to authorized users.

Alexander Bürkle

alexander.buerkle@uni-konstanz.de

$\triangle$ Aswin Mangerich

aswin.mangerich@uni-konstanz.de

1 Molecular Toxicology Group, Department of Biology, University of Konstanz, 78457 Konstanz, Germany

2 Konstanz Research School Chemical Biology, University of Konstanz, Konstanz, Germany

3 Department of Life Sciences, Albstadt-Sigmaringen University of Applied Sciences, Albstadt, Germany

\section{Introduction}

Thousands of DNA lesions occur in every cell during a day by the encounter with genotoxic agents form endogenous and exogenous sources. As a result, various DNA repair mechanisms have evolved during evolution to ensure genomic integrity (Ciccia and Elledge 2010). One of those mechanisms is nucleotide excision repair (NER)—a versatile molecular machinery involved in the removal of bulky and helix distorting DNA adducts (Marteijn et al. 2014). NER is unique among DNA repair mechanisms, since it detects a wide spectrum of DNA lesions only with a small set of common damage recognition and repair initiators. The underlying feature of all these structurally different DNA lesions is the varying degree of DNA kinking and helix distortion. The efficiency of lesion removal is mainly determined by 
the degree of distortion and thus the initial binding and verification of the lesion site (Marteijn et al. 2014). NER is a multistep process neatly choreographed by the sequential assembly of almost 30 proteins. The single steps involve initial damage recognition, local DNA unwinding and damage verification, dual incision on the damaged strand and removal of the lesion-containing oligonucleotide, re-synthesis of DNA, and sealing of the nick (Scharer 2013). Two sub-pathways can initiate the NER machinery, the globalgenome NER (GG-NER), responsible for maintenance of the whole genome, and the transcription-coupled NER (TC-NER), involved in the detection and removal of lesion sites in actively transcribed genes (Spivak 2015). Among the most common NER, lesions are UV-light-induced 6-4PPs' and CPDs' lesions, but also bulky DNA lesions caused by chemicals such as polycyclic aromatic hydrocarbons (PAH).

PAHs are a class of several hundred chemical compounds, many of which are known to be persistent environmental toxins, mutagens, and carcinogens (EPA 2006; Kim et al. 2013). One of those, benzo[a]pyrene (B[a]P), arises from incomplete combustion of organic matter and can be ubiquitously found in automobile exhaust, industrial emission, cigarette smoke, and charcoal-broiled meat. It has been detected in food and plants $(0.1-150 \mu \mathrm{g} / \mathrm{kg})$, drinking water (2.5-9 ng/l), and air (1.3-500 ng/m $\mathrm{m}^{3}$ ) (Angerer et al. 1997; Madureira et al. 2014). B [a]P is a pro-carcinogen and not reactive per se. However, upon entering the cell, it binds the aryl hydrocarbon receptor (AHR) and triggers the expression of the biotransforming CYP450 enzymes involved in xenobiotic metabolism. As a result, CYP1A1, CYP1B1, and the epoxide hydrolase $(\mathrm{mEH})$ convert $\mathrm{B}[\mathrm{a}] \mathrm{P}$ to the highly reactive, cytotoxic agent benzo[a]pyrene-7,8-dihydrodiol9,10-epoxide (BPDE), which reacts with DNA mainly at the $N^{2}$ position of guanine (Moserova et al. 2009). Doses of 0.01-0.1- $\mu \mathrm{M}$ BPDE form 800-9600 bulky DNA adducts, which can be detected and repaired by the NER pathway (Akerman et al. 2004; Gelboin 1980; Kim et al. 1998). However, if not repaired, BPDE-DNA adducts are the major cause for BPDE's toxicity, resulting in replicative stress and genomic instability. Treatment of cells with BPDE induces apoptosis via p53, BAX and JNK as well as necrosis, caused by $\mathrm{NAD}^{+}$depletion due to PARP1 overactivation (Donauer et al. 2012; Lin and Yang 2008; Wani et al. 2000). Furthermore, BPDE is highly mutagenic, potentially leading to tumorigenic transformation (Akerman et al. 2004; Deng et al. 2014; Dreij et al. 2005; Lin and Yang 2008; Pavanello et al. 2008).

PARP1 is involved in a broad spectrum of cellular processes, many of which are associated with genome maintenance (Ray Chaudhuri and Nussenzweig 2017). It has been reported to interact in particular with DNA single and double-strand breaks, however, also other substrates, such as UV-induced DNA damage, DNA hairpins and cruciform
DNA function as PARP1 substrates (Lonskaya et al. 2005; Purohit et al. 2016). In response to binding to different DNA structures, several modes of PARP1 activation are conceivable, probably resulting in varying degrees of catalytic activity. Thus, the magnitude of PARP1 activity depends on the type of DNA damage (e.g., blunt end vs. base overhang) (Benjamin and Gill 1980; D'Silva et al. 1999; Pion et al. 2005). In any case, upon activation, PARP1 uses NAD ${ }^{+}$as a substrate to covalently attach an ADP-ribose unit to itself (i.e., automodification) or other target proteins under the release of nicotinamide as a by-product. Subsequently, this mono(ADP-ribose) unit can be further elongated to form polymer chains of up to 200 moieties (Hottiger 2015; Ueda and Hayaishi 1985). PARP1 facilitates the repair of DNA lesions by a wide array of functions. For example, PARylation locally opens the chromatin and forms a platform to facilitate the recruitment and assembly of DNA repair factors, organizes access and removal of repair factors, and influences their enzymatic activities (Fischer et al. 2014; Posavec Marjanovic et al. 2016; Ray Chaudhuri and Nussenzweig 2017).

While the role of PARP1 in DNA strand break and base excision repair is well characterized, the understanding of its functions in response to bulky DNA lesions is only emerging. Recent studies suggested that PARP1 is an important factor for an efficient NER process and facilitates the removal of UV photoproducts (Fischer et al. 2014; Pines et al. 2012; Robu et al. 2013, 2017). PARP1 has been shown to physically interact with several factors of the NER machinery, to covalently or non-covalently modify them with PAR, and thus alter their functionality and subcellular localization. Thus, CSB interacts with PARP1 and PAR, and its ATPase activity was reported to be inhibited upon this interaction (Scheibye-Knudsen et al. 2014; Thorslund et al. 2005). XPC is modified with PAR in a covalent and non-covalent manner and is recruited to damage sites in a PARP1- and PAR-dependent manner (Robu et al. 2013, 2017). XPA has been shown to interact with PARP1 and $\mathrm{PAR}$, and this interaction functions as a reciprocal regulatory mechanism between the NER pathway and PARP1. Thus, XPA stimulates PARP1's catalytic activity, whereas PARylation regulates XPA's DNA-binding ability (Fischer et al. 2014; King et al. 2012). Furthermore, DDB2 has been shown to stimulate PARP1 activity in the presence of UV photoproducts, resulting in chromatin decondensation and recruitment of the chromatin remodeler ALC1. PARylation of DDB2 stabilizes the protein, preventing ubiquitination and proteasomal degradation (Luijsterburg et al. 2012; Pines et al. 2012).

The previous studies concerning the role of PARylation in the response to bulky DNA lesions mainly focused on its role in the response to UV-light-induced photoproducts. However, not all NER substrates are processed in the same 
manner and remarkable variations exist in the degree of damage recognition, efficiency and pace of lesion removal, as well as composition of essential NER factors (Lee et al. 2014; Marteijn et al. 2014; Robu et al. 2013; Wood 1999). Since the role of PARP1 in the response to chemicalinduced, bulky DNA adducts is largely uncharacterized, we addressed this question using the B[a]P metabolite BPDE. While our analyses did not identify a role for PARP1 in BPDE-induced NER mechanisms, we revealed a major protective role for PARP1 in BPDE-induced replication stress with significant functional consequences in terms of BPDEinduced cytotoxicity and mutagenicity.

\section{Materials and methods}

\section{Cell culture}

CHO, HeLa Wt, and HeLa PARPI knock-out cells (clones KO1 and KO2) (Rank et al. 2016) were cultured in DMEM (Thermo Fisher Scientific) supplemented with 10\% FCS, $100-\mathrm{U} / \mathrm{ml}$ streptomycin, and $100-\mu \mathrm{g} / \mathrm{ml}$ penicillin (termed 'complete growth medium'). Primary human foreskin fibroblasts were cultured in DMEM (Thermo Fisher Scientific), supplemented with $10 \%$ FCS and $50-\mu \mathrm{g} / \mathrm{ml}$ gentamycin. Cells were kept at $37{ }^{\circ} \mathrm{C}, 95 \%$ humidity, and $5 \% \mathrm{CO}_{2}$.

\section{BPDE treatment}

(+)-Anti-benzo[a]pyrene-7,8-dihydrodiol-9,10-epoxide (BIU, Biochemisches Institut für Umweltcarcinogene, Germany) was dissolved in water-free tetrahydrofuran (THF) supplemented with 5\% triethylamine (TEA). Aliquots of the stock solution $(10 \mathrm{mM})$ were snap-frozen in liquid nitrogen and stored at $-80^{\circ} \mathrm{C}$. Treatment of cells with BPDE was performed in cell culture medium without supplements. To keep the THF solvent concentration of the working solutions stable at $0.1 \%$, freshly prepared BPDE stock solutions were diluted (1:1000) in growth medium w/o supplements (termed 'incomplete growth medium'). If not specified otherwise, cells were treated for $1 \mathrm{~h}$ with BPDE at $37^{\circ} \mathrm{C}$, then medium was replaced with pre-warmed complete growth medium and cells were incubated further at the standard conditions until experimental readout.

\section{Immunochemical detection of BPDE-DNA adducts}

\section{Immunofluorescence microscopy}

HeLa cells were seeded on coverslips in 12 -well plates $\left(1 \times 10^{5}\right.$ cells per well). After incubation for 1 day, cells were treated with BPDE in incomplete DMEM for $1 \mathrm{~h}$ and washed afterwards thrice for $5 \mathrm{~min}$ in PBS. Cells were fixed with methanol:acetone $(1: 1)$ for $20 \mathrm{~min}$ at $-20^{\circ} \mathrm{C}$, air-dried, and treated with $0.05-\mathrm{M} \mathrm{HCl}$ for $5 \mathrm{~min}$ on ice. Samples were washed thrice for 5 min in PBS and incubated with RNaseA $(100 \mu \mathrm{g} / \mathrm{ml}$ in $150-\mathrm{mM} \mathrm{NaCl}, 1-\mathrm{mM}$ sodium citrate) for $1 \mathrm{~h}$ at $37{ }^{\circ} \mathrm{C}$. Thereafter, cells were incubated consecutively in PBS or EtOH (35\%-, 50\%-, and 75\%) for 3 min each. Next, DNA was denature in $150-\mathrm{mM} \mathrm{NaOH}$ in $70 \% \mathrm{EtOH}$ for 4 min, and washed twice in PBS. Cells were incubated for 2 min each in $70 \%$ EtOH containing $4 \%$ formaldehyde, in $50 \%$ and $35 \%$ EtOH. DNA was stained using Hoechst 33342 $(200 \mathrm{ng} / \mathrm{ml}$ in PBS) for $10 \mathrm{~min}$ at room temperature (RT) and subsequently treated with Proteinase $\mathrm{K}(10 \mu \mathrm{g} / \mathrm{ml}$ in $20 \mathrm{mM}$ Tris, 1-mM EDTA, pH 7.4) for $10 \mathrm{~min}$ at $37^{\circ} \mathrm{C}$. Cells were washed again thrice for $5 \mathrm{~min}$ in PBS before incubation in $20 \%$ FCS (in PBS) for $1 \mathrm{~h}$ at RT. Cells were washed thrice in $0.05 \%$ Tween 20 (in PBS) for 5 min and incubated with a primary antibody against BPDE-DNA adducts (Santa Cruz, $1: 50$ in PBS/5\% FCS) for $1 \mathrm{~h}$ at $37^{\circ} \mathrm{C}$ in a humid chamber. Again, cells were washed thrice in $0.05 \%$ Tween 20 (in PBS) and then incubated in secondary antibody solution (1:400 GoM-Alexa Fluor 488 in PBS/5\% FCS) for $1 \mathrm{~h}$ at $37{ }^{\circ} \mathrm{C}$ in a humid chamber. Coverslips were washed thrice for $5 \mathrm{~min}$ in PBS before they were mounted with Aqua-Polymount. Microscopic images of at least 100 cells were acquired with an Axiovert 200M microscope (Zeiss). Mean fluorescence intensity was determined using the ImageJ software.

\section{Slot-blot analysis}

One day after seeding of $6 \times 10^{5} \mathrm{HeLa}$ cells in $35-\mathrm{mm}$ petri dishes, the medium was removed and exchanged to incomplete DMEM supplemented with BPDE as indicated. Cells were incubated for $1 \mathrm{~h}$ at $37{ }^{\circ} \mathrm{C}$, afterwards trypsinized, and pelleted at $200 \times \mathrm{g}$ for $5 \mathrm{~min}$. The pellet was dissolved in 500- $\mu \mathrm{l}$ extraction buffer (100-mM Tris; $200-\mathrm{mM} \mathrm{NaCl}$; $0.2 \%$ SDS; 5-mM EDTA, $\mathrm{pH}$ 8.0) and $100-\mu \mathrm{g} / \mathrm{ml}$ Proteinase $\mathrm{K}$ was added and mixed by inversion. The cell lysate was incubated overnight in a thermomixer $\left(300 \mathrm{rpm} ; 55^{\circ} \mathrm{C}\right)$ and centrifuged on the next day at $13,000 \mathrm{rpm}$ for $5 \mathrm{~min} .500-\mu \mathrm{l}$ isopropanol were added to the supernatant and incubated for $>1 \mathrm{~h}$ at $20^{\circ} \mathrm{C}$. The lysate was centrifuged at $13,000 \mathrm{rpm}$ for $10 \mathrm{~min}$ at $4{ }^{\circ} \mathrm{C}$ and the resulting pellet was dissolved in $500-\mu \mathrm{l}$ ice-cold $\mathrm{EtOH}$. The sample was centrifuged again at $13,000 \mathrm{rpm}$ for $5 \mathrm{~min}$ at $4{ }^{\circ} \mathrm{C}$, the pellet air-dried, and dissolved in 50- $\mu \mathrm{l} \mathrm{TE} \mathrm{buffer.} \mathrm{Each} \mathrm{well} \mathrm{of} \mathrm{a} \mathrm{slot-blot} \mathrm{manifold}$ was pre-rinsed with 500- $\mu \mathrm{l} \mathrm{MilliQ} \mathrm{water} \mathrm{and} \mathrm{500- \mu l} 6 \times$ SSC buffer. Prior to sample loading, DNA was denatured by adding $\mathrm{NaOH}$ and EDTA to the final concentrations of $0.4 \mathrm{M}$ and $10 \mathrm{mM}$, respectively. Then, samples were incubated for 10 min at $95{ }^{\circ} \mathrm{C}$, diluted in TE, and applied on the slotblot manifold. The wells were rinsed again in $500-\mu \mathrm{NaOH}$ $(0.4 \mathrm{M})$ and the membrane was washed in $2 \times \mathrm{SSC}$ buffer. The air-dried membrane was incubated for $1 \mathrm{~h}$ in $5 \%$ skim 
milk in TBS-T. Afterwards, the blot was incubated for $1 \mathrm{~h}$ in a BPDE-DNA-specific antibody, diluted 1:400 in blocking buffer, and washed thrice for $5 \mathrm{~min}$ in TBS-T before incubation in secondary antibody solution (GoM HRP, 1:2000 in blocking buffer, $1 \mathrm{~h}$ ). The membrane was washed again in TBS-T and chemiluminescence was detected via ECL reaction.

\section{PAR detection}

HeLa cells were seeded in 60 -mm dishes $\left(6 \times 10^{5}\right.$ cells per dish) and cultured for 2 days to obtain a final amount of $\sim 6-7 \times 10^{6}$ cells. Medium was replaced with pre-warmed incomplete medium supplemented with or without $10-\mu \mathrm{M}$ ABT888 30 min prior to BPDE treatment. PAR formation was induced by replacing the medium containing 10or $50-\mu \mathrm{M}$ BPDE ( 0.1 or $0.5 \% \mathrm{THF}$, respectively) in prewarmed incomplete DMEM and incubation took place for $10,30,60$, or $90 \mathrm{~min}$. After washing with ice-cold PBS, cells were lysed with ice-cold 20\% TCA and detached mechanically using a cell scraper. The cell lysate was centrifuged for 4 min at $4{ }^{\circ} \mathrm{C}$ at $3000 \times g$, the supernatant was discarded, and the pellet washed twice with ice-cold $70 \% \mathrm{EtOH}$. Finally, the pellet was dried at $37{ }^{\circ} \mathrm{C}$ in a thermo shaker/thermomixer and stored at $-20^{\circ} \mathrm{C}$. PAR detection using isotope dilution mass spectrometry was performed as described previously (Martello et al. 2013; Zubel et al. 2017).

\section{$\mathrm{NAD}^{+}$cycling assay}

$\mathrm{NAD}^{+}$measurements were performed as described previously (Jacobson and Jacobson 1976), with modifications. HeLa cells $\left(1 \times 10^{5}\right.$ cells/well $)$ were seeded in 6 -well plates and treated with BPDE in concentrations as indicated in incomplete growth medium for $1 \mathrm{~h}$. BPDE was removed and cells were harvested directly or allowed to recover for 4 or $23 \mathrm{~h}$ in complete growth medium. Cell numbers were adjusted to $5 \times 10^{5}$ cells. After centrifugation for $5 \mathrm{~min}$ at $4{ }^{\circ} \mathrm{C}$ and $200 \times g$, the pellets were dissolved in 500- $\mu$ lice-cold PBS, and 24- $\mu$ cold 3.5-M $\mathrm{HClO}_{4}$ were added and mixed thoroughly. The reaction tubes were put on ice for $15 \mathrm{~min}$ and centrifuged again for $10 \mathrm{~min}$ at $4{ }^{\circ} \mathrm{C}$ and $1500 \times g$. The supernatant was transferred to new reaction tubes, mixed with 350- $\mu$ l phosphate buffer $\left(0.33-\mathrm{M} \mathrm{K}_{2} \mathrm{HPO}_{4} ; 0.33-\mathrm{M}\right.$ $\mathrm{KH}_{2} \mathrm{PO}_{4} ; \mathrm{pH}$ 7.5) and incubated on ice for an additional $15 \mathrm{~min}$. Again, the solutions were centrifuged for $10 \mathrm{~min}$ at $4{ }^{\circ} \mathrm{C}$ and $1500 \times g$. The supernatant was recovered and incubated on ice for $20 \mathrm{~min}$. Afterwards, samples were centrifuged $\left(10 \mathrm{~min}, 4{ }^{\circ} \mathrm{C}, 1500 \times g\right)$ and the supernatant was transferred to fresh reaction tubes. Samples were distributed in technical triplicates on a 96 -well plate $(40 \mu \mathrm{l} /$ well $)$ and mixed with $160-\mu$ diluent $\left(0.5 \mathrm{M} \mathrm{H}_{3} \mathrm{PO}_{4} ; 0.5 \mathrm{M} \mathrm{NaOH}\right)$. Immediately before measurement, 5 volumes of Premix solution (0.48 M bicine, $\mathrm{pH}$ 8.0; 4-mg/ml BSA; 20-mM EDTA; 2.4-M EtOH; 2-mM MTT) were mixed with one volume phenazine ethosulfate (PES, $40 \mathrm{mM}$, Santa Cruz) and one volume alcohol dehydrogenase $(\mathrm{ADH}, 1 \mathrm{mg} / \mathrm{ml}$, Sigma Aldrich). The resulting reaction mix $(100 \mu \mathrm{l})$ was added to every well, mixed thoroughly, and samples were incubated at $30{ }^{\circ} \mathrm{C}$. After $30 \mathrm{~min}$, the absorption was measured using a microplate reader (filterset $550 / 690 \mathrm{~nm}, A_{\max }$ at $570 \mathrm{~nm}$ ).

\section{Alamar blue assay}

HeLa cells were seeded in a 96-well plate $(100 \mu 1 /$ well; 6000 cells/per well) in technical triplicates or quadruplicates and incubated for $3 \mathrm{~h}$ at $37{ }^{\circ} \mathrm{C}$ for attachment. Thirty minutes prior to the treatment, medium was changed to fresh growth medium with or without 10- $\mu \mathrm{M} \mathrm{ABT888.} \mathrm{BPDE} \mathrm{was} \mathrm{diluted}$ in pre-warmed, incomplete DMEM, and applied to cells. After $1 \mathrm{~h}$ at $37{ }^{\circ} \mathrm{C}$, medium was changed again to fresh growth medium. In case of PARP inhibition, ABT888 was present during and after the BPDE treatment. After incubating the cells for $24 \mathrm{~h}$ or $45 \mathrm{~h}$, a $10 \%$ Alamar blue solution (Thermo Scientific) was added to each well. After additional $4 \mathrm{~h}$, fluorescence was measured using a Varioskan Flash fluorescence reader (Ex.: $535 \mathrm{~nm} / \mathrm{Em} .: 580 \mathrm{~nm}$ ).

\section{Annexin V/propidium iodide assay}

HeLa cells were seeded in 6 -well plates $\left(3 \times 10^{5}\right.$ cells per well) and incubated overnight. PARP inhibition was achieved by treating cells with $10-\mu \mathrm{M}$ ABT888 in incomplete medium $30 \mathrm{~min}$ prior to BPDE treatment. After $1 \mathrm{~h}$, BPDE was removed and the cells were further cultured in growth medium in the presence or absence of ABT888 for $48 \mathrm{~h}$. Afterwards, cells were washed with PBS and harvested by trypsination. Culture medium, PBS used for washing, and the harvested cells were collected and pooled. The cell suspension was centrifuged for $5 \mathrm{~min}$ at $1000 \mathrm{rpm}$, the pellet resuspended in ice-cold PBS, and the total cell number was determined. One million cells were centrifuged for $5 \mathrm{~min}$ at $4{ }^{\circ} \mathrm{C}$ and $1000 \times \mathrm{rpm}$ and resuspended in 1-ml Annexin $\mathrm{V}$ binding buffer (10-mM HEPES/NaOH, $\mathrm{pH} 7.4 ; 140-\mathrm{mM}$ $\mathrm{NaCl}$; and 2.5-mM $\mathrm{CaCl}_{2}$ ). Five microliters of Annexin V-FITC solution were added to $195 \mu$ of cell suspension and incubated in the dark for $15 \mathrm{~min}$. Subsequently, 200- $\mu \mathrm{l}$ PI staining solution (10-mM HEPES/NaOH, $\mathrm{pH} 7.4$; 140$\mathrm{mM} \mathrm{NaCl} ; 2.5-\mathrm{mM} \mathrm{CaCl}$; and $10-\mu \mathrm{g} / \mathrm{ml} \mathrm{PI)}$ was added and kept on ice until measurement. Unstained, as well as PI and Annexin V single-stained samples were prepared to establish and calibrate instrument parameters and correct gating. Measurement of 20,000 cells was performed with a BD FACSCalibur and results were analyzed with the FlowJo 8.8.7 software. 


\section{Clonogenic survival assay}

HeLa cells were trypsinized and cell numbers were determined in three replicates using a Casy cell counter (Roche). Cells were centrifuged for $5 \mathrm{~min}$ at $1000 \mathrm{rpm}$ and resuspended in incomplete medium to obtain a final concentration of $2 \times 10^{5}$ cells $/ \mathrm{ml}$. The cell suspension was distributed in $2-\mathrm{ml}$ reaction tubes $(1 \mathrm{ml}$ each) and incubated at $37{ }^{\circ} \mathrm{C}$ in the presence or absence of $10-\mu \mathrm{M}$ ABT888. After $10 \mathrm{~min}, 1 \mu \mathrm{l}$ of the freshly prepared $1000 \times \mathrm{BPDE}$ stock solution was added and mixed carefully by pipetting. Treatment was performed at $37^{\circ} \mathrm{C}$ for $30 \mathrm{~min}$. Cell suspensions were further diluted 1:100 in complete growth medium before 1000 cells were seeded in $60-\mathrm{mm}$ petri dishes in the presence or absence of $10-\mu \mathrm{M} \mathrm{ABT} 888$. In an alternative treatment schedule, ABT888-untreated cells were seeded and incubated for $6 \mathrm{~h}$ to allow attachment before adding 10- $\mu \mathrm{M} \mathrm{ABT888.} \mathrm{After} \mathrm{incubating} \mathrm{the} \mathrm{cells}$ for 7 days at $37{ }^{\circ} \mathrm{C}$, they were fixed with $10 \%$ PFA for 30 min and stained with $0.1 \%$ crystal violet (in PBS) for $45 \mathrm{~min}$. Excessive crystal violet was removed by repeated washing with MilliQ water and the dishes were air-dried and sealed with Parafilm. Colony numbers ( $>20$ cells/ colony) were determined using a binocular (Leica).

\section{Host cell reactivation assay}

To analyze the repair of BPDE-DNA lesions in a cellular, chromatin-independent context, a host cell reactivation assay (HCRA) was performed as described previously (Burger et al. 2010). To this end, human foreskin fibroblasts were

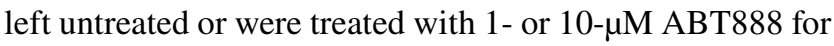
$30 \mathrm{~min}$. Thereafter, cells were harvested by trypsination and the resulting cell suspension was divided in two equal aliquots. One aliquot was transfected with a plasmid mix consisting of 3- $\mu \mathrm{g}$ pEGFP and 15- $\mu \mathrm{g}$ pDsRed plasmid ('preparation 1'). The other aliquot was transfected with a mix of the same plasmid quantities, but the pDsRed plasmid was treated with BPDE ('preparation 2'). The pDsRed plasmid $(500 \mu \mathrm{g} / \mathrm{ml})$ was treated with $75-\mu \mathrm{M}$ BPDE in the dark or left untreated. After $3 \mathrm{~h}$ of incubation, the plasmids were frozen at $-20{ }^{\circ} \mathrm{C}$ and stored until further processing. Transfection was performed in a 4-mm gap cuvette at $0.32 \mathrm{kV}$ and 500 $\mu \mathrm{F}$ with a GenePulser II (Bio-Rad). After electroporation, cells were seeded in 6-well plates in the presence or absence of ABT888. $24 \mathrm{~h}$ later, cells were harvested by trypsination and the fluorescence signals were analyzed with a FACSCalibur flow cytometer. Repair capacity was calculated from relative amounts of red fluorescent cells compared to green fluorescent cells between 'preparation 1' and 'preparation 2' for each treatment. Data were normalized to the untreated control.

\section{Analysis of reactive oxygen species}

HeLa cells were seeded in a 96-well plate $\left(8 \times 10^{3}\right.$ cells/ well) and incubated overnight. Medium was exchanged with phenol-red-free DMEM (31053, Gibco). As a positive control, cells were treated with $400 \mu \mathrm{M}$ of the ROS inducer tert-butyl hydroperoxide (TBHP) for $30 \mathrm{~min}$. As a negative control, cells were additionally treated with $5 \mathrm{mM}$ of the antioxidant $\mathrm{N}$-acetyl cysteine (NAC) for $1 \mathrm{~h}$ before TBHP treatment. Samples were treated with 10- or 50- $\mu$ M BPDE in incomplete phenol-red-free DMEM for periods as indicated in technical triplicates at $37^{\circ} \mathrm{C}$. Thereafter, $4-\mu \mathrm{M}$ dihydroethidium (DHE) was added, and after $30 \mathrm{~min}$ at $37^{\circ} \mathrm{C}$, fluorescence signals (Ex.: $520 \mathrm{~nm} / \mathrm{Em} .: 610 \mathrm{~nm}$ ) were acquired.

\section{Cell-cycle analysis}

Unsynchronized cell culture: HeLa cells were seeded in 6 -well plates $\left(4 \times 10^{5}\right.$ cells/well $)$ and incubated overnight. 30 min prior to BPDE treatment, medium was replaced with fresh growth medium supplemented with or without $10-\mu \mathrm{M}$ ABT888. BPDE treatment was performed in incomplete medium at $37^{\circ} \mathrm{C}$ for $1 \mathrm{~h}$. Thereafter, medium was replaced with complete growth medium and cells were cultured for $24 \mathrm{~h}$. On the next day, cells were harvested, pelleted by centrifugation for $5 \mathrm{~min}$ at $1000 \mathrm{rpm}$, and resuspended in $300-\mu 1$ cold PBS. The cell suspension was mixed by adding dropwise 700- $\mu 1$ ice-cold ethanol and kept on ice for $20 \mathrm{~min}$ or alternatively stored at $-20{ }^{\circ} \mathrm{C}$ overnight. Cells were centrifuged for $5 \mathrm{~min}$ at $4{ }^{\circ} \mathrm{C}$ and $200 \times g$, washed with $150-\mu \mathrm{l}$ ice-cold PBS, and again centrifuged for $5 \mathrm{~min}$ at $4{ }^{\circ} \mathrm{C}$ and $300 \times g$. This was repeated once, before the pellets were resuspended in 30- $\mu \mathrm{l} \mathrm{PBS}$ and mixed thoroughly with $120-\mu \mathrm{l}$ DNA extraction buffer (4-mM citric acid; $0.2-\mathrm{M} \mathrm{Na}_{2} \mathrm{HPO}_{4}$; $\mathrm{pH}$ 7.8). After 20 min under gentle agitation, cells were centrifuged for $5 \mathrm{~min}$ at $300 \times g$ and the pellet was resuspended in $200-\mu \mathrm{l}$ DNA staining solution $(20-\mu \mathrm{g} / \mathrm{ml}$ propidium iodide; $0.2-\mathrm{mg} / \mathrm{ml}$ DNase-free RNase A in PBS). Incubation was performed for $30 \mathrm{~min}$ at RT, before cells were stored on ice in the dark until measurements. The cell-cycle phase was determined by analysis of cellular PI signal as a marker of DNA content. 30,000 cells were measured with a BD FACSCalibur and results were analyzed with the FlowJo 8.8.7 software.

Synchronized cell culture: For cell-cycle synchronization, $3.2 \times 10^{6} \mathrm{HeLa}$ cells were seeded in T-75 culture flasks. On the next day, 500-nM nocodazole was added to the normal growth medium and cells were incubated for $12 \mathrm{~h}$ to induce a G2/M arrest. To further increase the degree of synchronization, a mitotic shake-off was performed. The supernatant, which contained M-phase cells, was taken off, centrifuged for $5 \mathrm{~min}$ at $200 \times g$, and washed twice in PBS. Four hundred thousand cells were seeded in 6 -well plates $\left(\mathrm{t}_{0}\right)$ and 
kept at $37{ }^{\circ} \mathrm{C} .10$ min prior to BPDE treatment, the medium was replaced with DMEM without or supplemented with $10-\mu \mathrm{M} \mathrm{ABT} 888.10 \mathrm{~h}$ after seeding $\left(\mathrm{t}_{10}\right)$, BPDE treatment was performed in incomplete medium at $37^{\circ} \mathrm{C}$. Afterwards, cells recovered in complete growth medium. At $\mathrm{t}_{11}, \mathrm{t}_{14}, \mathrm{t}_{18}$, $t_{24} t_{26}, t_{29}$, and $t_{32}$, cells were washed with PBS, harvested, and prepared for cell-cycle analysis as described for unsynchronized cells.

\section{YH2A.X immunostaining}

HeLa cells were seeded in 6 -well plates $\left(3 \times 10^{5}\right.$ cells/well) and incubated overnight. $30 \mathrm{~min}$ prior to BPDE treatment, cells were treated with $10-\mu \mathrm{M} \mathrm{ABT} 888$ or left untreated. Then, cells were exposed to 50-nM BPDE in incomplete medium in the presence or absence of ABT888. After $1 \mathrm{~h}$, BPDE was replaced with growth medium (supplemented with ABT 888 or left untreated) and incubated at $37{ }^{\circ} \mathrm{C}$ for periods as indicated. Before harvesting, cells were washed with PBS and $100-\mu$ pre-heated $\left(95^{\circ} \mathrm{C}\right) 2 \times$ SDS loading dye was applied to the cells and incubated for $2 \mathrm{~min}$. Cells were detached from the plate with a cell scraper and the cell lysates were collected in $1.5-\mathrm{ml}$ reaction tubes. Immediately thereafter, the solutions were heated again to $95{ }^{\circ} \mathrm{C}$ for $5 \mathrm{~min}$. DNA was sheared by repeated passaging through a 27-gauge needle. Cell lysates were heated again for $5 \mathrm{~min}$ to $95{ }^{\circ} \mathrm{C}$, and $10 \mu \mathrm{l}$ of each sample was subjected to a $15 \%$ SDS-PAGE and subsequent wet-blotting. The blot was cut in half according to target protein sizes $(\sim 15 \mathrm{kDa}$ for $\gamma \mathrm{H} 2 \mathrm{~A} . \mathrm{X}$ and $\sim 42 \mathrm{kDa}$ for actin) and membranes were incubated in blocking solution (5\% skim milk in TBS-T). For actin, $\gamma \mathrm{H} 2 \mathrm{~A}$.X-staining membranes were incubated for $1 \mathrm{~h}$ in primary antibody solutions [1:50,000 $\alpha$-actin and 1:2000 $\alpha-\gamma$ H2A.X (MAB1501 and JBW301, Merck) in blocking buffer] and afterwards washed thrice for $5 \mathrm{~min}$ in TBS-T. Subsequently, membranes were incubated in secondary antibody solution for $1 \mathrm{~h}$ [1:2000 goat-anti-mouse-HRP (DakoCytomation) in blocking buffer], followed by washing thrice with TBS-T for $5 \mathrm{~min}$. Chemiluminescence signals were detected after applying ECL solution (Lumigen) with an ImageQuant LAS 4000 (GE Healthcare).

\section{Immunofluorescence microscopy}

Co-staining of $\gamma \mathrm{H} 2 \mathrm{~A} . \mathrm{X}$ and EdU: HeLa cells were seeded on coverslips in 12 -well plates $\left(1 \times 10^{5}\right.$ cells/well $) 1$ day before the experiment. $20 \mathrm{~min}$ before BPDE treatment, cells were incubated in $10-\mu \mathrm{M}$ EdU, which was also present during BPDE exposure ( $1 \mathrm{~h}, 150 \mathrm{nM})$. Cells were washed thrice with PBS, and subsequently incubated in complete growth medium. At timepoints of 1, 2, 4, and $8 \mathrm{~h}$ after damage induction, cells were fixed with 4\% PFA/PBS for $20 \mathrm{~min}$ at RT. After a 5-min washing step with PBS, samples were treated with $50-\mathrm{mM} \mathrm{NH}_{4} \mathrm{Cl} / \mathrm{PBS}$ for $10 \mathrm{~min}$. Cells were washed again with PBS $(2 \times$ for $5 \mathrm{~min})$, permeabilized with $0.2 \%$ Trition $\mathrm{X}-100 / \mathrm{PBS}$ for $4 \mathrm{~min}$, and washed again ( $2 \times$ for 5 min in PBS). Blocking occurred in $1 \%$ BSA in PBS for 30 min at RT before cells were incubated overnight at $4{ }^{\circ} \mathrm{C}$ in primary antibody solution (anti- $\gamma \mathrm{H} 2 \mathrm{AX}, 1: 500$ in blocking buffer) in a humid chamber. On the next day, cells were washed consecutively for 5,10 , and $15 \mathrm{~min}$ in PBS. Secondary antibody solution [goat-anti-mouse Alexa Fluor 488 (Molecular Probes)] was diluted 1:400 in blocking buffer and cells were incubated for $45 \mathrm{~min}$ at RT in a humid chamber. Thereafter, cells were washed again for 5,10 , and 15 min with PBS. To detect the incorporated thymidine analogue EdU, a click reaction was performed with a fluorescent azide (Click-iT Plus Kit, Thermo Scientific) according to the manufacturer's instructions.

Co-staining of $\gamma \mathrm{H} 2 \mathrm{~A} . \mathrm{X}$ and 53BP1: Sample treatment and preparation was performed as described for the $\gamma \mathrm{H} 2 \mathrm{~A} . \mathrm{X} /$ EdU co-staining with some variations. Here, simultaneous to the first antibody staining with $\gamma \mathrm{H} 2 \mathrm{~A}$.X, cells were coincubated with rabbit anti-53BP1 antibody (1:200, H-300, SataCruz). The same applies for the incubation with the secondary antibody (goat-anti-rabbit Alexa Fluor 568, 1:400, Molecular Probes). Confocal microscopy was performed on a Zeiss LSM780 and $>100$ cells per condition were analyzed. Data were evaluated using ImageJ and numbers of $\gamma \mathrm{H} 2 \mathrm{~A}$.X foci per cell or their co-localization with foci of 53BP1 were defined using the BIC Macro Toolkit (BIC, University of Konstanz).

\section{HPRT mutagenicity assay}

Pre-existing HPRT mutant cleansing (HAT selection): Three million CHO cells were seeded in T-160 cell culture flasks. The next day, medium was replaced with complete growth medium supplemented with HAT (hypoxanthine-aminopterin-thymidine) for HPRT mutant removal. Cells were cultured in HAT selection medium for $72 \mathrm{~h}$. Thereafter, HAT medium was replaced with HT medium (hypoxanthine-aminopterin) and cells were allowed to recover for $48 \mathrm{~h}$.

BPDE treatment and phenotypic expression: Cells were re-seeded in 6-well plates $\left(3 \times 10^{5}\right.$ cells/well $)$ and allowed to adhere overnight. 30 min before BPDE treatment, cells were treated with $10-\mu \mathrm{M}$ ABT888 or left untreated. CHO cells were incubated at $37{ }^{\circ} \mathrm{C}$ in incomplete medium supplemented with BPDE in the presence or absence of ABT888. After $1 \mathrm{~h}$, BPDE was removed, and cells were washed once with PBS and incubated for $23 \mathrm{~h}$ in fresh growth medium. On the next day, cell numbers were readjusted to $3 \times 10^{5}$ cells/well and cells were incubated for 11 days (w/ or w/o ABT888), with sub-culturing every other day. Afterwards, cells were harvested and cell numbers were determined. A number of $2 \times 10^{5}$ cells were re-seeded in selection medium 
(supplemented with 40- $\mu \mathrm{M}$ 6-thioguanine, 6-TG). Mutant selection went on for a period of 8 consecutive days, during which medium and 6-TG were refreshed once after 4 days of culturing. Simultaneously, plating efficiency ( $\mathrm{PE}=$ mean colony number/ seeded cells) was analyzed by seeding defined numbers of $\mathrm{CHO}$ cells in technical triplicates and culturing without selection pressure. If applied, $10 \mu \mathrm{M}$ of ABT888 was present always both in mutant selection and platingefficiency media. After 8 days, cells were carefully washed once with PBS and fixed with 10\% PFA for $30 \mathrm{~min}$. Colonies were stained with $0.05 \%$ crystal violet for $30 \mathrm{~min}$ and repeatedly washed with MilliQ water. The plates were air-dried and sealed with parafilm and colonies were counted. Cell clusters with more than 20 cells in diameter were defined as countable colonies. Mutant frequency (MF) was calculated as mean colony number (selective conditions)/(PE $\left.\times 2 \times 10^{5}\right)$.

\section{Results}

The previous studies analyzed the role of PARP1 in NER in response to UV-light-induced DNA damage (Pines et al. 2012; Robu et al. 2013, 2017; Vodenicharov et al. 2005). However, whether and how PARP1 and PARylation are involved in the cellular response to bulky DNA lesions caused by chemical compounds such as B[a]P metabolites is largely unexplored. The prime purpose of this study was to investigate the role of PARP1 and PARylation in BPDEinduced genotoxic stress response and to address the underlying cellular mechanisms.

\section{BPDE induces a cellular PARylation response}

After verifying that BPDE indeed causes DNA adducts in treatment conditions as applied in this study (Suppl. Figure 1), we tested if BPDE can induce PARylation in HeLa cells using a highly sensitive bioanalytical method based on isotope dilution mass spectrometry (LC-MS/MS) (Martello et al. 2013; Zubel et al. 2017) (Fig. 1). Since we recently generated HeLa cells with genetic PARP1 deletion (mutation) via TALEN-mediated gene targeting (Rank et al. 2016), this cell line was chosen as a model system. In a dose-response experiment, cells were treated with BPDE for $1 \mathrm{~h}$ and PAR levels were determined via LC-MS/MS. After exposure to $\geq 10-\mu \mathrm{M}$ BPDE, a significant increase in PAR formation was observed (Fig. 1a). When treating cells with 50- $\mu \mathrm{M}$ BPDE in a short-term time series, PAR levels started to rise after $10 \mathrm{~min}$, reached a significant threefold induction after $30 \mathrm{~min}$, and declined afterwards by $90 \mathrm{~min}$. ABT888 was used as a specificity control and, as expected, completely inhibited BPDE-induced PAR formation (Fig. 1b). Exemplary LC-MS/MS chromatograms are shown in Suppl. Figure 2. When performing a long-term
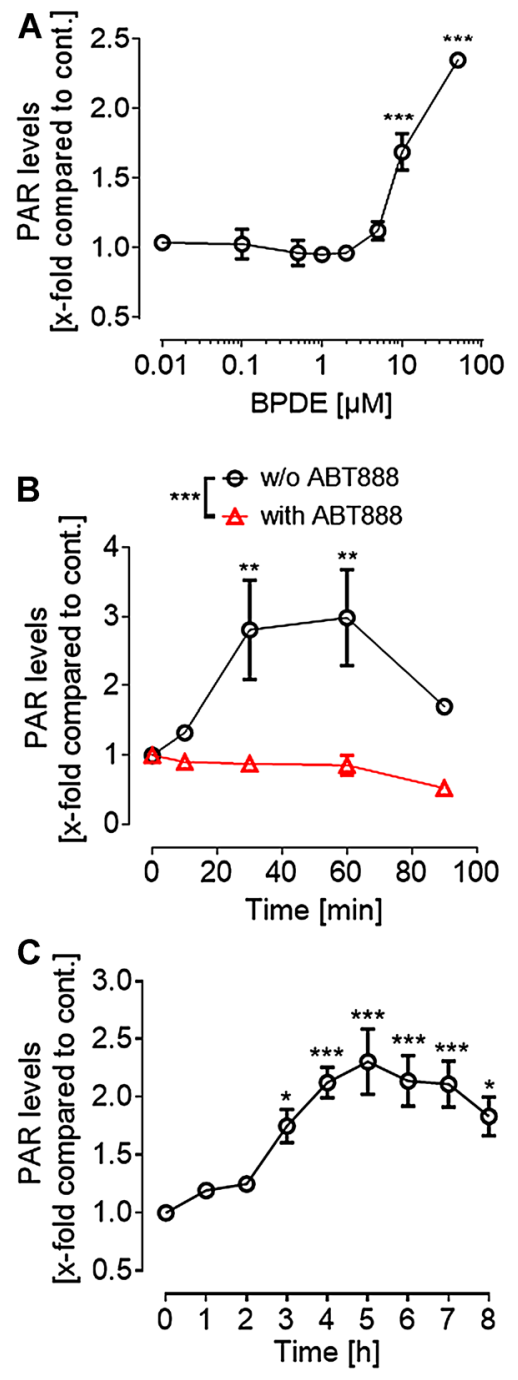

Fig. 1 LC-MS/MS analysis of BPDE-induced PAR formation in HeLa cells. a Dose-response analysis of BPDE-induced PAR formation. Cells were treated for $1 \mathrm{~h}$ with BPDE in concentrations as indicated. Afterwards, PAR levels were determined via LC-MS/MS. b Short-term time series of PAR formation after treatment with $50 \mu \mathrm{M}$ of BPDE. Cells pre-incubated in 10- $\mu$ M ABT888 showed no PARylation in response to BPDE treatment. c Long-term time series of PAR formation after $10-\mu \mathrm{M}$ BPDE treatment. PAR levels continuously increased for the first $5 \mathrm{~h}$ after damage induction. Data represent means \pm SEM $(n=3)$ normalized to untreated and solvent control, respectively. Statistical evaluation was performed using one-way a, c or two-way ANOVA, b analyses followed by Sidak's multiple comparison testing. $* p<0.05$, ** $p<0.01$, *** $p<0.001$. For exemplary LC-MS/MS chromatograms, refer to Suppl. Figure 2

time series after treatment of cells with 10- $\mu \mathrm{M}$ BPDE, a steady increase of PAR levels was observed reaching a plateau phase after $4-5 \mathrm{~h}$ (Fig. 1c). Thereafter, the PAR signal decreased slowly until 8-h post treatment. These LC-MS/ MS analyses demonstrate-with full chemical specificity-that BPDE induces a cellular PARylation response. 


\section{BPDE exposure affects cellular NAD ${ }^{+}$levels}

PAR formation relies on its substrate $\mathrm{NAD}^{+}$, which can lead to a significant depletion of $\mathrm{NAD}^{+}$pools in case of strong or long-lasting PARP stimulation. In severe cases, this can result in a metabolic catastrophe and energy crisis (Fouquerel and Sobol 2014). To analyze if BPDE-induced PARylation affects cellular $\mathrm{NAD}^{+}$levels, a quantitative $\mathrm{NAD}^{+}$cycling assay was performed (Fig. 2). Unlike the PARylation response induced by $\mathrm{H}_{2} \mathrm{O}_{2}$ (Rank et al. 2016), PARP activation upon BPDE treatment occurred with slower kinetics, but was lasting for several hours (Fig. 1c). Thus, cells were treated with BPDE for $1 \mathrm{~h}$ and $\mathrm{NAD}^{+}$levels were determined either directly or 4 and $23 \mathrm{~h}$ after BPDE treatment. Neither concentration of BPDE changed NAD ${ }^{+}$levels directly after treatment (Fig. 2a). Yet, when cells were treated with $2-\mu \mathrm{M}$ BPDE, NAD ${ }^{+}$levels declined by $50 \%$ within $4 \mathrm{~h}$ after exposure. The decrease of $\mathrm{NAD}^{+}$could be rescued almost completely when cells were incubated with ABT888. Treating cells with a lower concentration of 250nM BPDE had no influence on cellular NAD ${ }^{+}$levels even $4 \mathrm{~h}$ after treatment (Fig. 2b). Interestingly, $23 \mathrm{~h}$ after treatment with $2-\mu \mathrm{M}$ BPDE, $\mathrm{NAD}^{+}$levels were still reduced by $20 \%$ (Fig. 2c), suggesting a long-lasting moderate stimulation of PARP1 activity. Consistent with the notion that decreases in $\mathrm{NAD}^{+}$levels result from PARP1 activation, $\mathrm{NAD}^{+}$levels were rescued by PARP inhibitor treatment as well as genetic deletion of $P A R P 1$. Strikingly, when cells were exposed to a lower concentration of 250-nM BPDE, a twofold increase of $\mathrm{NAD}^{+}$levels as compared to solvent control was observed $23 \mathrm{~h}$ after treatment, irrespective of PARP inhibitor treatment or genetic ablation of PARPI (Fig. 2c). These results demonstrate that BPDE exposure significantly influences cellular $\mathrm{NAD}^{+}$metabolism in a complex and at least in part in a PARP1-dependent manner.

\section{PARP inhibition protects HeLa cells from short-term BPDE-induced toxicity}

To test if PARP activation and the alterations in $\mathrm{NAD}^{+}$levels influence BPDE-induced toxicity, we tested if co-treatment of BPDE and ABT888 affects cell proliferation and/ or cytotoxicity. As expected, when using the Alamar Blue assay to analyze cell proliferation and metabolic activity, we observed a significant decline in cellular activity $24 \mathrm{~h}$ after BPDE treatment at concentrations $\geq 100 \mathrm{nM}$. Interestingly, this decline in cellular activity was slightly, yet statistically significant, inhibited by ABT888 treatment (Fig. 3a). Consistent with these results, the same trend was observed in two independently generated HeLa cell lines carrying a genetic deletion of PARP1 (Fig. 3b, c). Notably, the protecting/inhibitory effect of ABT888 was only visible $24 \mathrm{~h}$ after BPDE treatment, since $45 \mathrm{~h}$ upon BPDE exposure, no
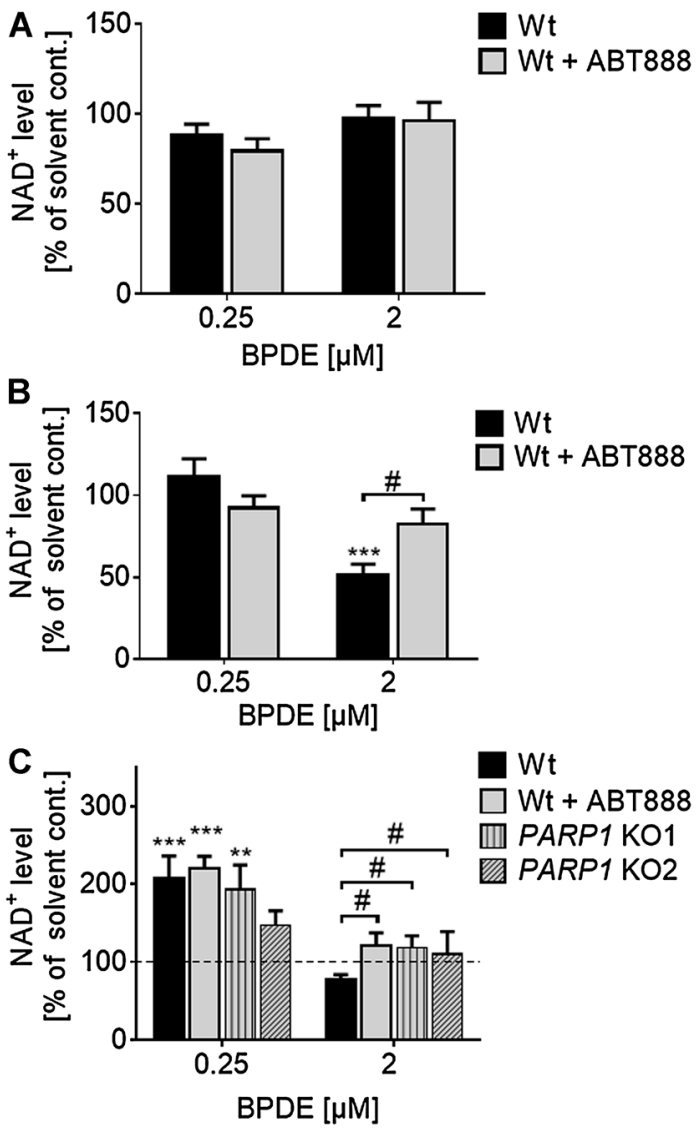

Fig. 2 Analysis of cellular $\mathrm{NAD}^{+}$levels upon BPDE treatment. $\mathrm{NAD}^{+}$levels of HeLa cells were determined by an enzymatic $\mathrm{NAD}^{+}$ cycling assay (Jacobson and Jacobson 1976). a, b Cells were treated with BPDE for $1 \mathrm{~h}$ in concentrations as indicated and $\mathrm{NAD}^{+}$levels were analyzed either directly (a) or $4 \mathrm{~h}$ (b) after treatment. $4 \mathrm{~h}$ after treatment with $2-\mu \mathrm{M}$ BPDE, $\mathrm{NAD}^{+}$levels decreased significantly, which could be inhibited by PARP inhibition (b). c Cells were treated with BPDE for 1 h. 23 h later, NAD ${ }^{+}$levels were analyzed. After treatment with $0.25-\mu \mathrm{M}$ BPDE, $\mathrm{NAD}^{+}$levels increased significantly independent of PARP inhibition or genetic deletion of PARP1. In contrast, after treatment with $2-\mu \mathrm{M}$ BPDE, $\mathrm{NAD}^{+}$levels dropped in HeLa Wt cells, but remained unchanged in HeLa PARP1 knockout $(\mathrm{KO})$ cells. Data were normalized to solvent control and represent means \pm SEM of $\geq 3$ independent experiments; each performed in technical triplicates. Statistical evaluation was performed using two-way ANOVA analysis followed by a Sidak's multiple comparison test $(*)$ or using non-parametric two-tailed $t$ tests $(\#) .{ }^{\#} p<0.05$, $* * p<0.01, * * * p<0.001$

significant difference of BPDE-induced cytotoxicity was observed between ABT888-treated and non-treated cells (Fig. 3d). ABT888 treatment or genetic deletion of PARPI alone had no effect on cellular activity in the Alamar Blue assay (Suppl. Figure 3). Since PARP activation and NAD ${ }^{+}$ depletion may result in enhanced cell death (Fouquerel and Sobol 2014), we next analyzed potential effects of BPDE and ABT888 co-treatment on cellular apoptosis and necrosis by Annexin V/PI staining (Suppl. Figure 4). Significant BPDEinduced cell death was observed at concentrations $\geq 2 \mu \mathrm{M}$ at 

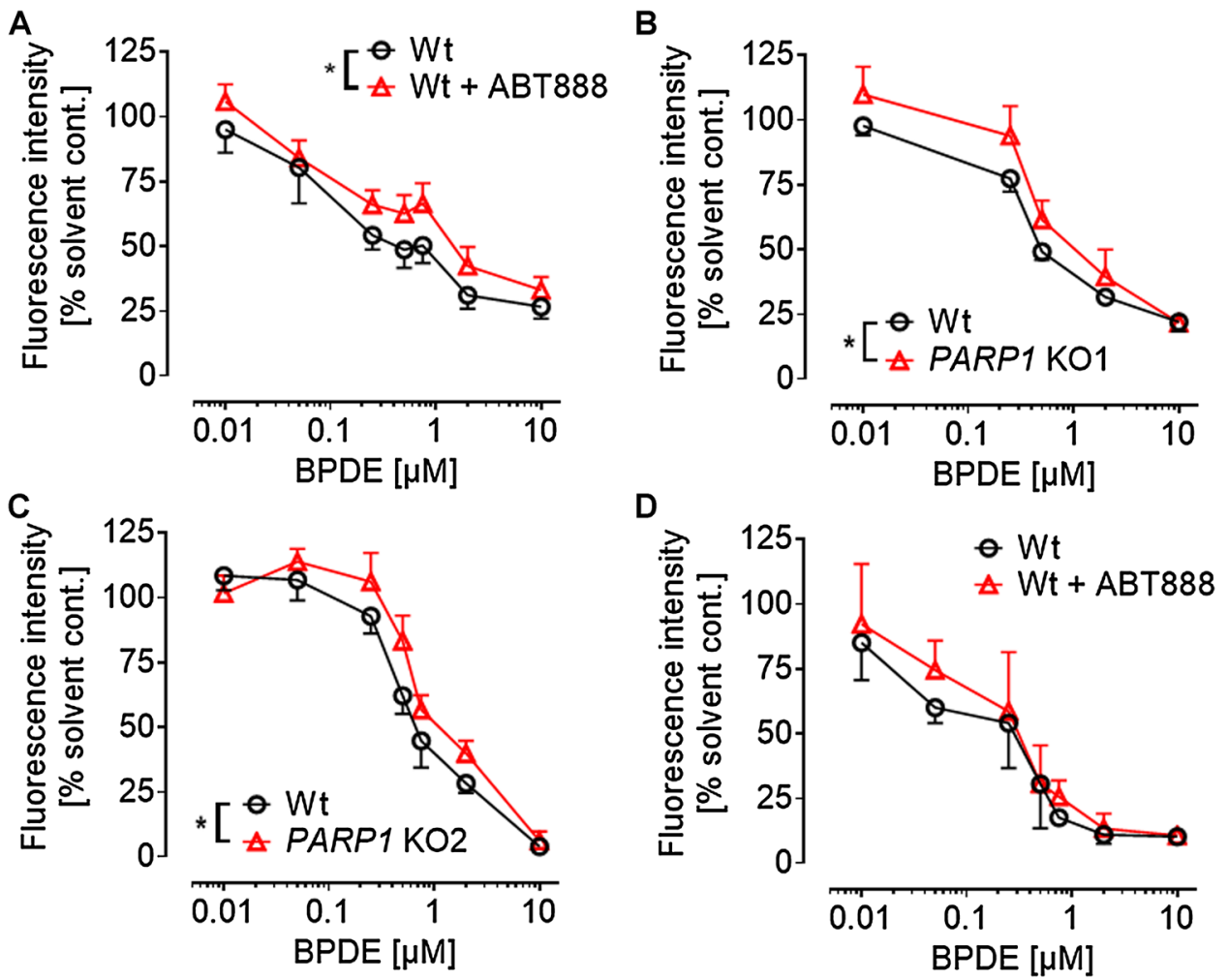

Fig. 3 Genetic PARP1 ablation or PARP inhibition protects from BPDE-induced short-term cytotoxicity. Alamar Blue assays were performed with HeLa cells to analyze the influence of PARP1 activity on cell proliferation and metabolic activity $24 \mathrm{~h}$ or $45 \mathrm{~h}$ after BPDE treatment. a Cells were treated with increasing concentrations of BPDE and incubated for $24 \mathrm{~h}$ before analyzing fluorescence intensities. ABT888 $(10 \mu \mathrm{M})$ partially protected from BPDE-induced cytotoxicity. b, c Genetic ablation of PARPI also protected cells from BPDE-induced cytotoxicity. Alamar Blue assays were performed $24 \mathrm{~h}$ after BPDE treatment. Both PARP1 knock-out cell lines (KO1

$45 \mathrm{~h}$ after treatment. In contrast to results obtained with the Alamar Blue assay, no effect of ABT888 co-treatment was observed. These results suggest that PARP activation and changes in $\mathrm{NAD}^{+}$levels were sufficient to affect the influence of BPDE on cell proliferation; however, changes in $\mathrm{NAD}^{+}$levels were too mild to significantly influence BPDEinduced cell death.

\section{Ablation of PARylation sensitizes cells to BPDE treatment in the clonogenic survival assay}

Colony formation assays were performed to test for functional implications of PARylation in BPDE-induced longterm toxicity. As expected, BPDE treatment alone had a strong influence on colony formation. A concentration of 100-nM BPDE reduced the number of colonies by $80-90 \%$, while a concentration of 200-nM already completely inhibited colony growth (Suppl. Figure 5 and Fig. 4). The solvent THF itself had no influence on colony formation of

and $\mathrm{KO} 2$ ) were significantly more resistant to BPDE-induced toxicity compared to HeLa Wt cells. d When the same assay was conducted $45 \mathrm{~h}$ after BPDE treatment, the protective effect of ABT888 was diminished and did not reach statistical significance. For solvent control, see Suppl. Figure 3. Data represent means \pm SEM of $\geq 3$ independent experiments, and each performed in $\geq 3$ technical replicates, normalized to solvent control. Statistical evaluation was performed using two-way ANOVA analysis followed by Sidak's multiple comparison testing. $* P<0.05$

HeLa cells. Since ABT888 treatment alone led to smaller and fewer colonies, independent of BPDE treatment (Suppl. Figure 5), colony numbers were normalized to corresponding solvent controls. ABT888 was applied $10 \mathrm{~min}$ before, directly after, or $6 \mathrm{~h}$ after plating of BPDE-treated cells. ABT888 treatment directly after exposure was performed with the purpose to exclude any potential unknown chemical interactions between ABT888 and BPDE. ABT888 treatment $6 \mathrm{~h}$ after plating was conducted to analyze potential effects of co-treatment with BPDE and ABT888 on cell attachment. PARP inhibition strongly sensitized cells to BPDE and fewer colonies were formed at any BPDE concentration tested, irrespective of the timepoint when ABT 888 was applied. The results observed upon treatment with ABT888 were verified using HeLa PARPI KO cell lines. Both PARPI KO cell lines showed comparable responses as seen upon ABT888 treatment, thus genetic deletion of PARP1 also strongly potentiated BPDE's cytotoxic effects (Fig. 4d, e). 
A

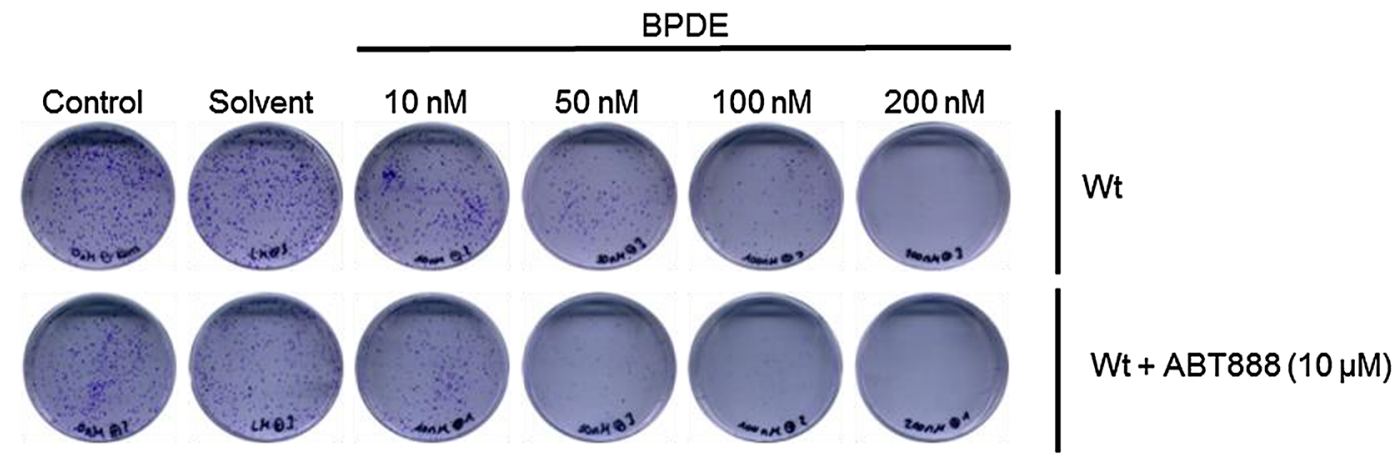

B
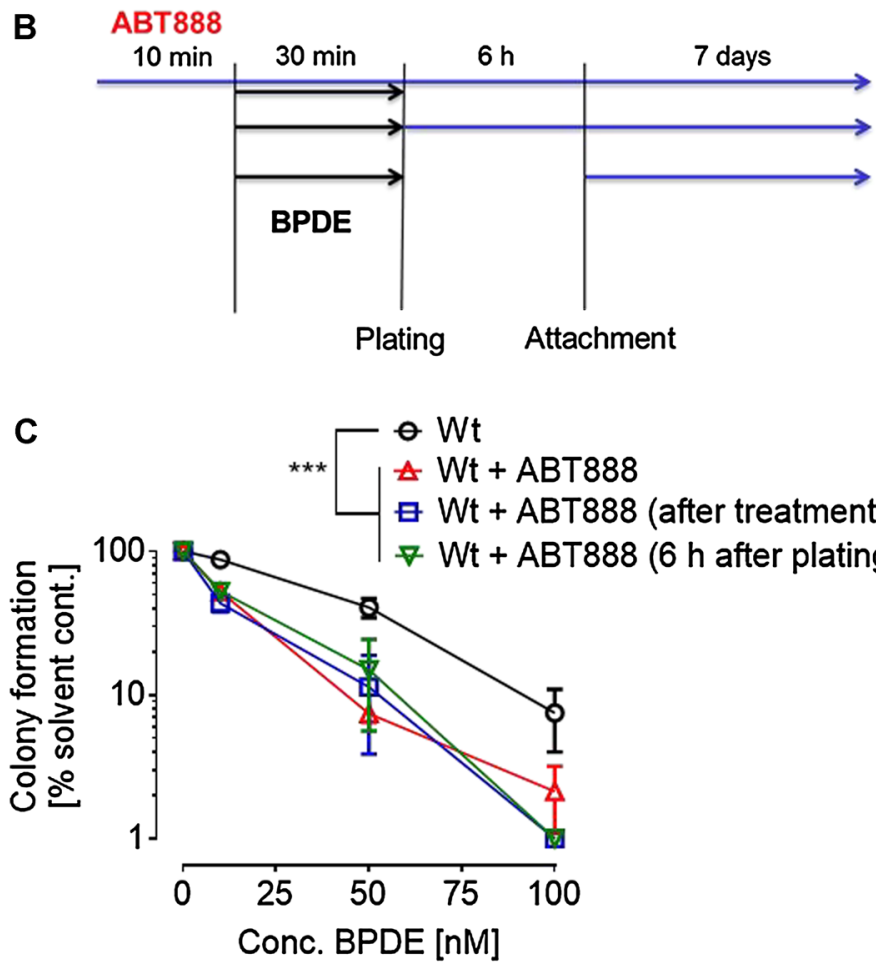

Fig. 4 PARP inhibition or genetic PARP1 ablation potentiates BPDE's long-term toxicity. HeLa Wt or PARP1 knockout (KO1/ $\mathrm{KO} 2$ ) cells were treated with increasing concentrations of BPDE for 30 min and clonogenic survival assays were performed by incubating cells for 7-day posttreatment. a Representative cell culture dishes showing results from a clonogenic survival assay performed with cells treated with BPDE in concentrations as indicated. In all experiments, no colony formation was observed upon 200- $\mu$ M BPDE treatment. b Scheme showing the different treatment schedules to test for the importance of timing of PARP inhibition and BPDE exposure. Three different treatment schedules were tested. c Quantification of clonogenic survival assays described in (b). Red: ABT888 was present before, during, and after BPDE treatment. Blue: ABT888 was

\section{PARP inhibition does not influence the repair of BPDE-DNA lesions in an HCRA}

Since colony formation assays (Fig. 4) revealed an important role for PARP activity in the cellular response to BPDE exposure, we tested if PARP activity may play a direct role

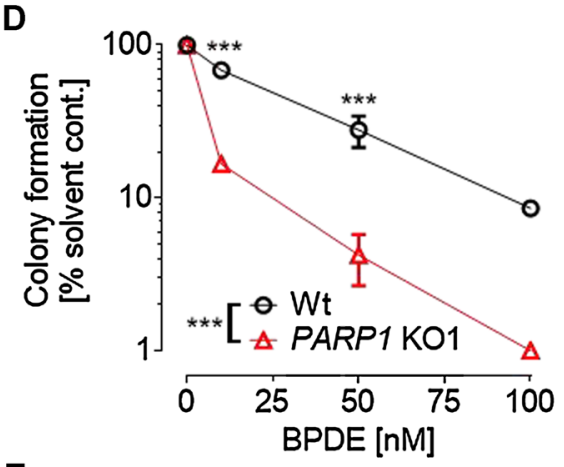

E

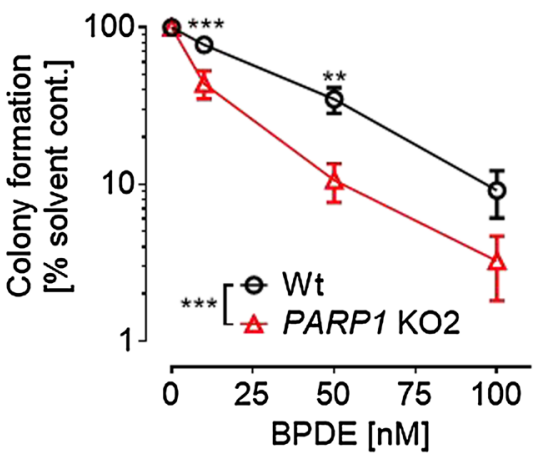

added directly after the treatment. Green: ABT888 was added $6 \mathrm{~h}$ after BPDE exposure. No major influence on BPDE's toxicity could be observed when altering the timing of PARP inhibition. All three ABT888 approaches showed significantly less colonies than the ABT888-untreated one while displaying only minor differences inbetween the different ABT888 treatment schedules. d, e Similar to pharmacological PARP inhibition, genetic PARP1 ablation also potentiated BPDE's induced long-term cytotoxicity. Data represent means \pm SEM of $\geq 3$ independent experiments and each performed in technical triplicates, normalized to solvent control. For control assays, see Suppl. Figure 5. Statistical evaluation was performed using twoway ANOVA analysis followed by Sidak's multiple comparison testing. $* p<0.05, * * p<0.01, * * * p<0.001$. (Color figure online)

in the removal of BPDE-DNA adducts using a previously developed host cell reactivation assay (HCRA) (Burger et al. 2010) (Suppl. Figure 6). While $24 \mathrm{~h}$ after transfection, the cellular DNA repair machinery restored about $60 \%$ of the transfected cells carrying the BPDE-treated plasmids, no effect of PARP inhibitor treatment was evident. These results 
suggest that PARylation may play no or only a minor role in the direct removal of BPDE-induced DNA adducts in a chromatin-independent repair environment.

The previous studies reported that reactive oxygen species (ROS) can be formed upon B[a]P treatment during CYP450dependent metabolism (Briede et al. 2004). To exclude that BPDE itself may trigger ROS formation in HeLa cells, which could lead to an indirect activation of PARP1, we performed a DHE-based assay to analyze potential cellular ROS formation. As it is evident from Suppl. Figure 7, no or only minor changes in ROS levels were observed upon treatment of cells with BPDE in concentrations of up to $50 \mu \mathrm{M}$, which is consistent with results from a recent report (Christmann et al. 2016).

\section{PARylation deficiency mildly affects cell-cycle progression in response to BPDE exposure}

To test if the sensitization effect of ABT888 in the colony survival assay may have been caused alterations in cell-cycle progression, we employed PI staining coupled to flow cytometric analysis.

First, unsynchronized cells were treated with or without ABT888 in combination with increasing doses of BPDE. After $24 \mathrm{~h}$, a cell-cycle analysis was performed (Suppl. Figure 8). BPDE caused a G2 arrest (right panel) in a dose-dependent manner. The co-incubation with ABT888 enhanced this effect when cells were treated with 100$\mathrm{nM}$ BPDE. The number of cells in $\mathrm{S}$ phase did not appear to be affected, neither by BPDE treatment alone nor by
BPDE-ABT888 co-treatment. When cells were exposed to higher doses of BPDE, no significant differences between PARP-inhibited and non-inhibited cells could be observed. Doses higher than 0.5- $\mu \mathrm{M}$ BPDE caused a very strong intra$\mathrm{S}$-phase arrest independent of PARP inhibition (data not shown).

To clarify potential PARP-dependent effects on cell-cycle progression, cells were synchronized before BPDE exposure (Fig. 5). At the timepoint of BPDE treatment, cells were at the border between G1 $(60 \%)$ and $\mathrm{S}$ phases (30\%). Figure 5a shows the progression of cells through the cell cycle without BPDE treatment (solvent control). In this case, PARP inhibition alone had no influence on cell-cycle progression. However, as it is evident from Fig. 5b, BPDE treatment led to a cell-cycle arrest in $\mathrm{G} 2$ phase, starting $8 \mathrm{~h}$ after exposure (Fig. 5b). ABT888 treatment had a statistically significant effect on cell-cycle progression by enhancing the proportion of cells in $\mathrm{G} 2$ phase $14 \mathrm{~h}$ after BPDE treatment.

\section{BPDE treatment of PARP1-deficient cells leads to an accumulation of DSB}

\section{PARylation-deficient cells display increased $\mathrm{pH} 2 \mathrm{AX}$ levels}

The sensitization of cells to BPDE exposure by ABT888 treatment in the clonogenic survival analysis suggested a role of PARP1 within the BPDE-induced replication stress response. Phosphorylation of the core histone $\mathrm{H} 2 \mathrm{~A}$.X on serine $139(\gamma \mathrm{H} 2 \mathrm{~A} . \mathrm{X})$ is a sensitive indicator for both DNA damage and replication stress (Szilard et al. 2010). The
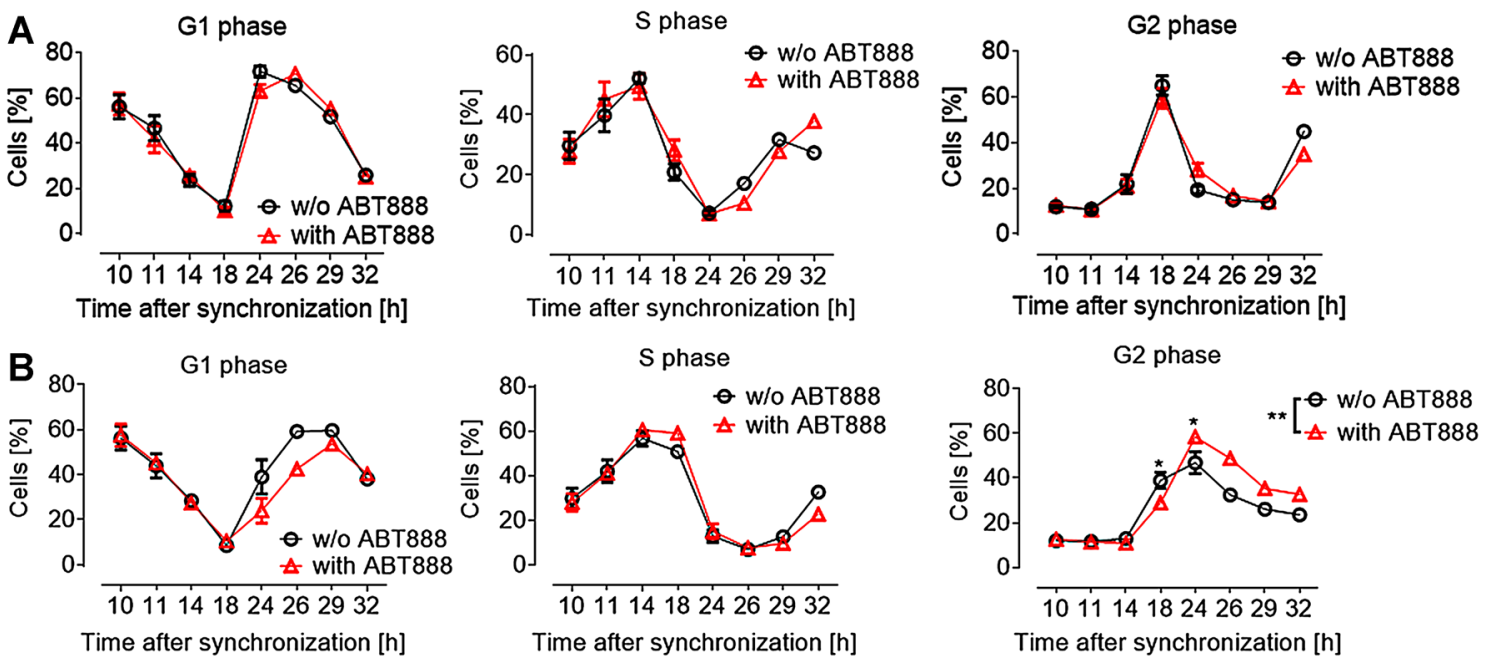

Fig. 5 PARP inhibition affects BPDE-induced cell-cycle delay. a PARP inhibition in the absence of BPDE had no significant influence on cell-cycle progression within the period analyzed. b BPDE treatment (at $t=10 \mathrm{~h}, 0.1 \mu \mathrm{M}$ for $1 \mathrm{~h}$ ) of synchronized HeLa cells caused a G2-phase arrest. Additional PARP inhibition further enhanced G2-phase arrest, resulting in decreased cell numbers re-entering the cell cycle. a, b. Data represent means \pm SEM of $\geq 3$ independent experiments $\left(n=1\right.$ for $t_{26-32}$ ), normalized to solvent control. Statistical evaluation was performed using two-way ANOVA analysis followed by Sidak's multiple comparison test. ${ }^{*} p<0.05$, $* * p<0.01$. Results from unsynchronized cells are shown in Suppl. Figure 8 
$\gamma \mathrm{H} 2 \mathrm{~A} . \mathrm{X}$ signal was followed in a time-course experiment after BPDE treatment (Fig. 6a). In untreated as well as in solvent-treated cells, only a weak $\gamma \mathrm{H} 2 \mathrm{~A}$.X signal could be detected, indicating no influence of the solvent itself on $\gamma \mathrm{H} 2 \mathrm{~A} . \mathrm{X}$ levels. However, in both controls (untreated and solvent control), the absence of PARP activity resulted in a slight increase in $\gamma \mathrm{H} 2 \mathrm{~A}$.X signals even without DNA damage induction. CPT treatment, which served as positive control, resulted in strongly elevated levels of $\gamma \mathrm{H} 2 \mathrm{~A} . \mathrm{X}$ compared to the untreated controls, again displaying stronger signal intensities for PARPI KO cells. Exposure of cells to BPDE resulted in continuously increasing amounts of $\gamma \mathrm{H} 2 \mathrm{~A} . \mathrm{X}$. Already, 2-4 h after treatment, an increase in signal intensity could be observed, which further rose until $48 \mathrm{~h}$ after BPDE exposure. The absence of PARP activity visibly amplified the signal intensity for $\gamma \mathrm{H} 2 \mathrm{~A} . \mathrm{X}$ further, with PARP1 KO1 cells showing even stronger signals than the ABT888-treated samples (Fig. 6a).

To discriminate/determine whether the $\gamma \mathrm{H} 2 \mathrm{~A}$.X signaling was a direct response to the BPDE-DNA damage or an indirect result due to BPDE-induced replicative stress, an immunofluorescence analysis of replicating as well as non-replicating cells was performed. Cells were pulselabeled with EdU, which is incorporated into the DNA during $\mathrm{S}$ phase, and were simultaneously treated with BPDE. Thereafter, both substances were removed and cells
Fig. 6 S-phase cells immediately responded to BPDE with increased $\gamma \mathrm{H} 2 \mathrm{~A}$.X signaling. a HeLa Wt and PARP1 KO1 cells were treated with $50-\mathrm{nM}$ BPDE for $1 \mathrm{~h}$. After periods as indicated, cells were lysed and subjected to SDS-PAGE and subsequent immunoblotting to detect $\gamma \mathrm{H} 2 \mathrm{~A}$.X. Already early after BPDE-dependent damage induction, an increase in $\gamma \mathrm{H} 2 \mathrm{~A}$.X signaling could be observed. Signal intensity steadily increased until 2 days after BPDE treatment. The absence of PARP activity $(10-\mu \mathrm{M}$ ABT888) or genetic deletion of PARP1 further enhanced this damage response. Shown is one representative experiment out of three independent experiments. Actin served as loading control. b-d 20 min before as well as during BPDE treatment $(150 \mathrm{nM})$, cells were pulselabeled with EdU. S-phase cells were identified by means of EdU incorporation. b Representative images of immunofluorescence-based detection of $\gamma \mathrm{H} 2 \mathrm{~A}$.X signaling in EdUpositive and EdU-negative cells. The scale bar represents $20 \mu \mathrm{m}$. c Quantification $\gamma$ H2A.X foci in EdU-negative cells. Only a minor increase of $\gamma \mathrm{H} 2 \mathrm{~A}$.X foci numbers could be detected 4-8 $\mathrm{h}$ after BPDE exposure. $\mathbf{d}$ In S-phase cells, foci numbers immediately increased upon BPDE treatment. Note the different scale of the $y$-axis. $\mathbf{c}, \mathbf{d}$ Data represent means \pm SEM of three independent experiments

A $50 \mathrm{nM}$ BPDE

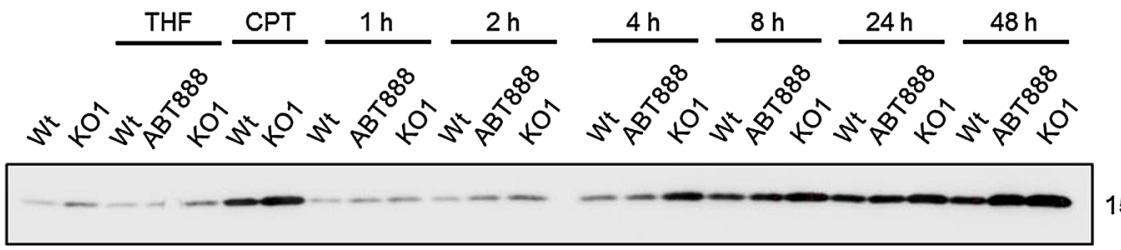
$15 \mathrm{kDa}$

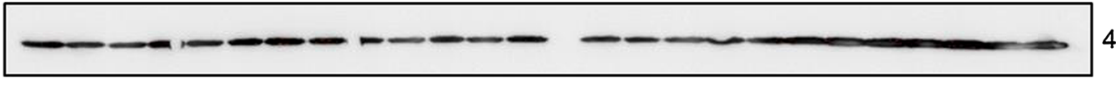
$42 \mathrm{kDa}$

B \begin{tabular}{l|l}
$\begin{array}{r}\text { Solvent } \\
\text { control }\end{array}$ & Wt \\
BPDE & PARP1 KO1 \\
$2 \mathrm{~h}$ & PARP1 KO1
\end{tabular}

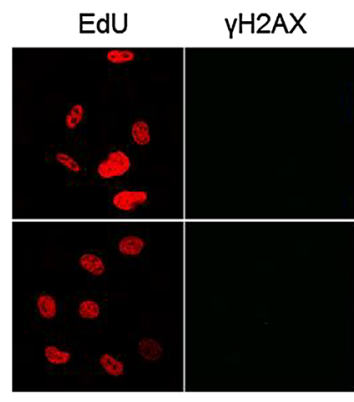

Hoechst Merge

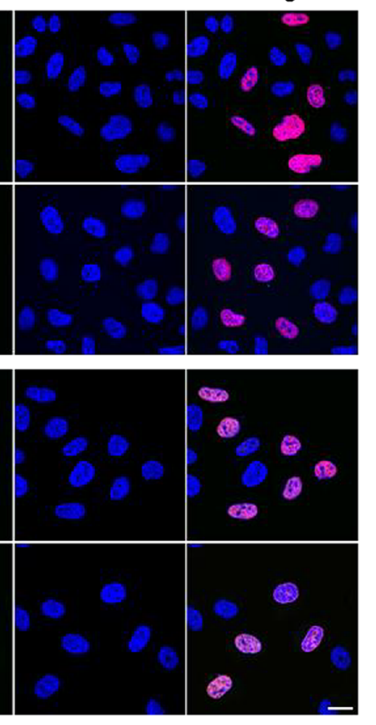

C

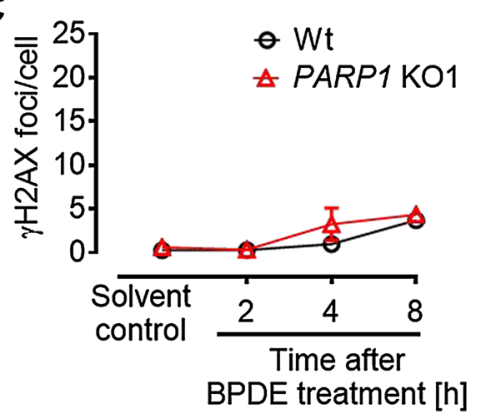

D

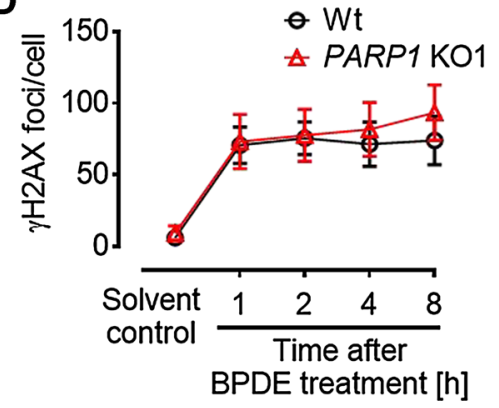


were cultured further. This setup allowed to discriminate between cells which were in $\mathrm{S}$ phase (EdU positive) and all other cell-cycle phase cells (EdU negative) at the time of BPDE treatment (Fig. 6b). Staining for $\gamma \mathrm{H} 2 \mathrm{~A}$.X clearly revealed that $\gamma \mathrm{H} 2 \mathrm{~A}$.X signaling was due to BPDE-induced replication stress. Cells which were in $\mathrm{S}$ phase at the time of BPDE exposure immediately responded strongly to BPDE treatment, giving rise to an average of $70-80$ foci per cell. In contrast, during the first $8 \mathrm{~h}$ after BPDE exposure, only a moderate increase of $\gamma \mathrm{H} 2 \mathrm{~A}$.X foci could be observed in EdU-negative cells, probably marking cells which have not entered replication (Fig. 6c, d). The finding that the $\gamma \mathrm{H} 2 \mathrm{~A}$.X response strongly lagged the BPDE exposure, suggested that the underlying cause is not the BPDE-DNA lesions as such, but their faulty procession during replication. If BPDE itself triggered the DDR, a faster response would be expected. Interestingly, the loss of PARP1 protein did not significantly alter the number of $\gamma \mathrm{H} 2 \mathrm{~A}$.X foci in immunofluorescence analysis (Fig. 6c, d).
Probably, the most serious outcome of replication stress is the collapse of stalled replication forks and the formation of DSBs. Having observed increased levels of $\gamma \mathrm{H} 2 \mathrm{~A}$.X in PARylation-deficient cells compared to Wt cells after BPDE exposure (8-24 h) in Western blot analyses (Fig. 6a), a double staining of $\gamma \mathrm{H} 2 \mathrm{~A} . \mathrm{X}$ and 53BP1 was performed to analyze the impact of PARylation on replication stress-induced DNA double-strand breaks (DSBs) (Fig. 7). $24 \mathrm{~h}$ after treatment with 150-nM BPDE, a pronounced co-localization of $\gamma \mathrm{H} 2 \mathrm{~A} . \mathrm{X}$ and 53BP1 was observed, which is indicative of DNA double-strand break formation. When these experiments were performed with a PARPI KO cell line, even after low-dose treatment with 50-nM BPDE, a significant increase in $\gamma \mathrm{H} 2 \mathrm{~A} . \mathrm{X} / 53 \mathrm{BP} 1$ was evident (Fig. 7b), which further increased to an average of $\sim 37$ foci per cell when cells were treated with 150-nM BPDE (as compared to 19 $\gamma$ H2A.X/53BP1 foci in HeLa Wt cells) (Fig. 7c). These results demonstrate that BPDE treatment in the absence of PARP activity led to DNA double-strand breaks specifically
Fig. 7 PARP1 deficiency sensitizes cells to BPDE-induced DSB formation. HeLa Wt and PARP1 knockout (KO1) cells were exposed to BPDE, and at the timepoints indicated, immunofluorescence-based detection of 53BP1 (red channel) and $\gamma$ H2A.X (green channel) was performed. a Representative images of cells exposed to 150-nM BPDE. On the bottom right, a digitally magnified PARP1 KO1 cell is displayed, demonstrating co-localization of 53BP1 and $\gamma \mathrm{H} 2 \mathrm{~A}$.X foci. b Quantification of co-localization of $\gamma \mathrm{H} 2 \mathrm{~A} . \mathrm{X}$ and 53BP1 foci in cells treated with 50-nM BPDE. c Quantification of co-localization of $\gamma \mathrm{H} 2 \mathrm{~A}$.X and 53BP1 foci in cells treated with $150-\mathrm{nM}$ BPDE. b, c PARPl knockout strongly enhanced the numbers of 53BP1 and $\gamma \mathrm{H} 2 \mathrm{AX}$ foci co-localization. Data represent means \pm SEM of three independent experiments. Statistical evaluation was performed using two-way ANOVA analysis followed by Sidak's multiple comparison testing. ${ }^{*} p<0.05$, $* * p<0.01, * * * p<0.001$. (Color figure online)

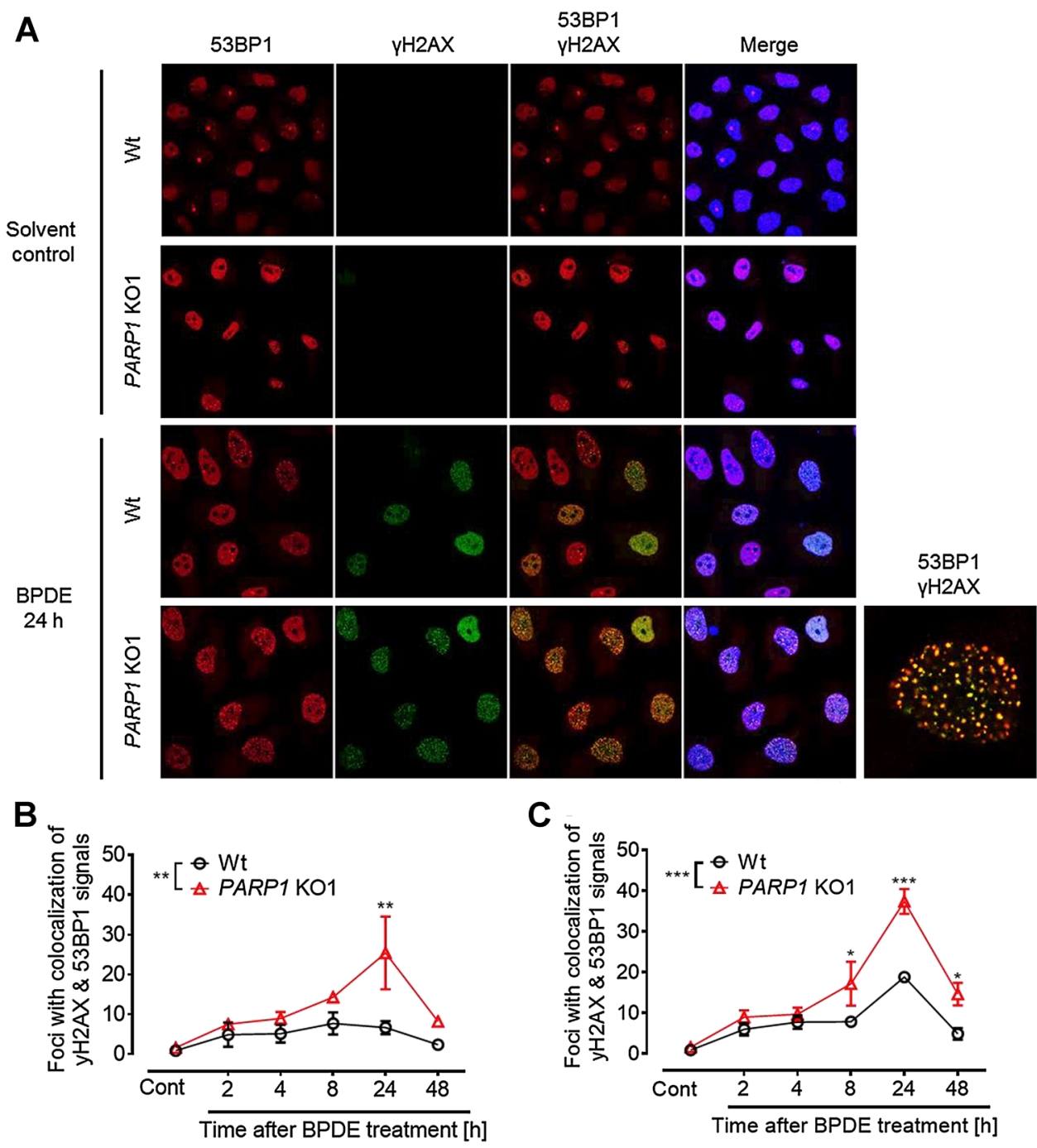


in S-phase cells, which are indicative of collapsed replication forks.

\section{Inhibition of PARylation increases the mutagenicity of BPDE}

BPDE is a highly mutagenic substance (Newbold and Brookes 1976). To address the question whether PARP activity affects BPDE's mutagenic potential, an HPRT mutation assay was performed (Fig. 8). Consistent with results from the colony formation assays in HeLa cells, ABT888 treatment of $\mathrm{CHO}$ cells also resulted in smaller colonies. As expected, increased BPDE concentrations strongly enhanced the mutation frequency in CHO HPRT genes (Fig. 8) leading to $\sim 1000$ surviving mutants per 1 million cells at a concentration of 500-nM BPDE. PARP inhibition itself, in the absence of BPDE treatment, had little influence on the mutation load observed in the HPRT assay. In contrast, when cells were treated with ABT888 in addition to BPDE, significantly enhanced numbers of mutant colonies were

A

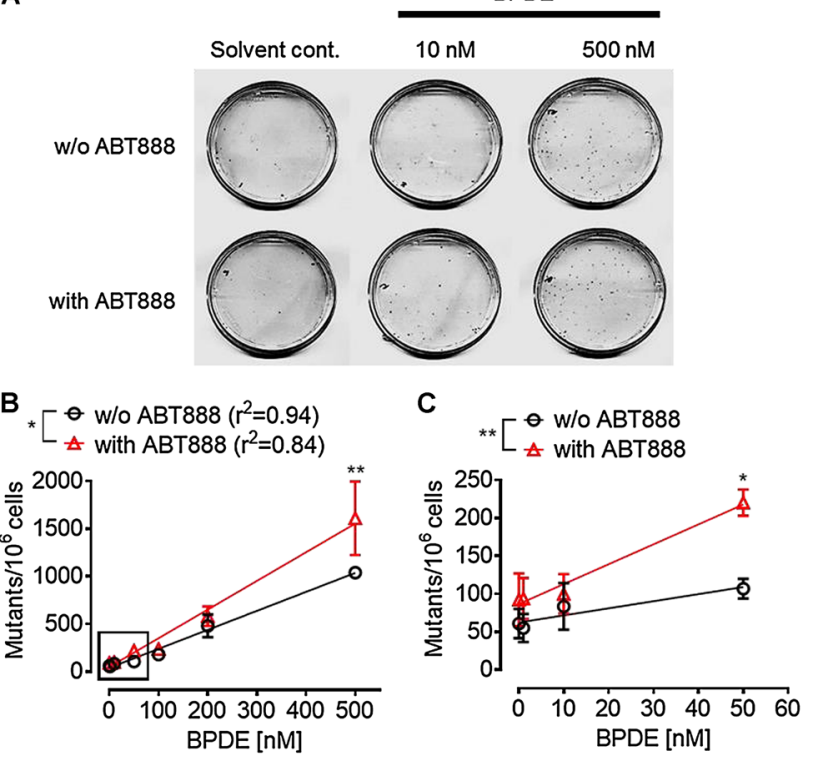

Fig. 8 PARP inhibition potentiates BPDE-induced mutagenicity. An $H P R T$ mutagenicity assay with BPDE-treated $\mathrm{CHO}$ cells was performed in the absence or presence of $10-\mu \mathrm{M}$ ABT888. a Representative cell culture dishes of the HPRT assay. A BPDE dose-dependent increase in colony numbers (mutant frequency) was observed. PARP inhibition further increased BPDE-induced mutagenicity. b, c Quantification of (a) increasing concentrations of BPDE resulted in increased numbers of mutations of the HPRT gene. b BPDE treatment with concentrations of up to $500 \mathrm{nM}$. c Magnification of insert in B showing data of the low-dose range, with BPDE concentrations of up to $50 \mathrm{nM}$. When PARP activity was inhibited, an even higher mutation rate was observed. Data represent means \pm SEM of four independent experiments. Statistical evaluation was performed using two-way ANOVA analysis followed by Sidak's multiple comparison testing. ${ }^{*} p<0.05,{ }^{* *} p<0.01$ observed, i.e., 1,500 mutant colonies per 1 million cells, indicating an increased mutagenic potential of BPDE in the absence of PARylation. Since PARylation appeared to be of little importance for direct BPDE-DNA lesion repair (Suppl. Figure 6), this increase is likely to be a direct response to potential replicative stress in PARylation-deficient cells.

\section{Discussion}

Benzo[a]pyrene is a potent and widespread environmental carcinogen and serves as lead model substance to study the response of cells to chemical-induced, bulky DNA adducts that are repaired by NER (Angerer et al. 1997, EPA 2006; Kim et al. 2013; Madureira et al. 2014; Piberger et al. 2017). While there is ample evidence that PARP1 participates in the removal of UV-induced DNA damage during NER (Fischer et al. 2014; Pines et al. 2012; Purohit et al. 2016; Robu et al. 2013, 2017; Vodenicharov et al. 2005), the understanding of how PARP1 participates in genotoxic stress response to chemical-induced, bulky DNA adducts is understood incompletely. Two previous studies provided initial insight into the role of PARylation in B[a]P-induced genotoxic stress. (Lin and Yang 2008; Tao et al. 2009). On one hand, Lin and Yang reported that treatment of HepG2 cells with micromolar concentrations of $\mathrm{B}[\mathrm{a}] \mathrm{P}$ led to $\mathrm{NAD}^{+}$consumption and PARP-dependent cell death (Lin and Yang 2008). On the other hand, Tao et al. reported that $\mathrm{B}[\mathrm{a}] \mathrm{P}$ treatment in micromolar concentrations caused more DNA strand breaks in human bronchial epithelial cells depleted for PARP1 as compared to Wt cells, whereas no PARP1-dependent effect on BPDE-induced cytotoxicity was observed. Moreover, PARP1-depleted cells showed a delay in strand break repair (Tao et al. 2009). While these studies provided first evidence that PARylation plays a role in $\mathrm{B}[\mathrm{a}] \mathrm{P}$-induced genotoxic stress, the detailed mechanisms of how PARylation is involved herein remained unclear. Since the use of $\mathrm{B}[\mathrm{a}] \mathrm{P}$ as a test compound can lead to ROS formation during xenobiotic metabolism (Briede et al. 2004), it cannot be excluded that in these studies, PARP is activated indirectly by ROS-induced DNA damage. In the present study, we took up the question on the role of PARylation in $\mathrm{B}[\mathrm{a}] \mathrm{P}$ genotoxicity by applying its active metabolite BPDE. In agreement with a recent study (Christmann et al. 2016), we observed no or only minor ROS formation when using BPDE as a genotoxic agent, thus rendering it possible to study PARylation-dependent effects specifically for BPDE-DNA adducts. With this, we now provide a comprehensive molecular toxicological analysis on the role of PARP1 and PARylation in BPDE-induced genotoxic stress by employing genetic and pharmacological approaches in combination with a broad spectrum of toxicological and molecular endpoints. As an experimental model system, we used HeLa wild-type cells treated with PARP 
inhibitor or untreated as well as HeLa PARPl knock-out cells, which have been recently generated using TALENmediated gene targeting (Rank et al. 2016).

We demonstrate here for the first time that BPDE directly induces a sustained PARylation response, using a highly sensitive LC-MS/MS approach (Fig. 1). The overall dynamics in PAR formation upon BPDE treatment differ considerably from other genotoxins, such as $\mathrm{H}_{2} \mathrm{O}_{2}$. While $\mathrm{H}_{2} \mathrm{O}_{2}$ causes a strong, but fast PARylation response within $<15$ min (Rank et al. 2016), BPDE triggered a rather moderate, but sustained PARP activation ( $>8 \mathrm{~h}$ ), potentially reflecting the kinetics and dynamics of the different DNA damage responses. We observed a PARP1-dependent decline in intracellular $\mathrm{NAD}^{+}$ pools after treatment with low micromolar concentrations of BPDE (Fig. 2), which is in line with results from Lin and Yang (Lin and Yang 2008). Interestingly, with low nanomolar concentrations of BPDE, we observed an increase in $\mathrm{NAD}^{+}$levels 1 day after treatment, which was independent of PARP1 activity. The reasons for this PARP1-independent increase in $\mathrm{NAD}^{+}$levels are unclear at the moment and need further evaluation. The PARP1-dependent decline of intracellular $\mathrm{NAD}^{+}$is consistent with the finding that pharmacological PARP inhibition as well as genetic PARPI ablation led to slight, yet statistically significant, cytoprotective effects within the first $24 \mathrm{~h}$ after BPDE treatment (Fig. 3). In contrast, however, when analyzing the colony forming ability of HeLa cells after low nanomolar BPDE exposure 7 days after treatment, a strong PARP1-dependent sensitization effect towards BPDE was observed. This observation led to the initial assumption of an active role of PARP1 in the NER of BPDE-induced lesions, similar to what was reported for the role of PARP1 in the repair of UV-induced DNA lesions (Pines et al. 2012; Purohit et al. 2016; Robu et al. 2013, 2017; Vodenicharov et al. 2005). Using an HCRA, with which we previously showed a role for PARP activity in the repair of UV-induced DNA damage (Fischer et al. 2014), we now demonstrate that this assay can also be used to efficiently monitor the repair of BPDE-induced DNA lesions in extrachromosomal plasmid DNA (Suppl. Figure 6). However, in contrast to UV-induced damage, no influence of PARP activity was evident. This finding can potentially be explained by the fact that UV-induced and chemical-induced bulky adducts are not necessarily repaired in the same manner. Thus, e.g., the UV-damaged DNA-binding protein 2 (DDB2) is likely to participate in the removal of UV-DNA adducts, but not in the recognition of bulky adducts and crosslinks, because these lesions do not fit into the DDB2-binding pocket (Robu et al. 2017; Scrima et al. 2008). Interestingly, in particular, DDB2 has been shown to cooperate with PARP1 in the repair of UV-induced DNA damage (Pines et al. 2012; Robu et al. 2013), suggesting that the different outcomes on the role of PARylation in the repair of UV lesions and BPDE-DNA adducts indeed have a molecular basis.

The finding of a strong PARP1-dependent increase in 53BP1/yH2A.X foci after nanomolar treatment with BPDE (Fig. 7) points towards replication stress as an alternative NER-independent mechanism of how PARP1 participates in BPDE stress response. 53BP1/yH2A.X foci are indicative of DNA double-strand breaks, which can arise as a consequence of collapsed replication forks during replication stress (Gaillard et al. 2015; Panier and Boulton 2014; Rothkamm et al. 2015; Scully and Xie 2013). In general, a role for PARP1 in the replication stress response has been well established. Bryant et al. found that PARP1 binds to and becomes activated by stalled replication forks (Bryant et al. 2009), where it stabilizes the 'chicken foot' structure via inhibition of untimely RECQ1-mediated branch migration, thus providing time for DNA lesion removal before replication restart (Berti et al. 2013; Ray Chaudhuri et al. 2012). Furthermore, when stalled replication forks collapse and form one-ended DSBs, PARP1 facilitates HRmediated repair and replication restart by recruitment of MRE11. PARP1 inhibition or knockout would in turn result in increased replication stress and a more dominant formation of DSBs and delayed repair of the latter (Berti et al. 2013; Bryant et al. 2009; Haince et al. 2008; Ray Chaudhuri et al. 2012).

To what extent BPDE can induce replication stress is not very well studied, but it would be plausible that BPDEDNA adducts block fork progression during DNA synthesis. Consistently, a previous report showed that BPDE-DNA adducts are enriched at replication forks (Paules et al. 1988). In consequence, this could lead to fork stalling, collapsing and the formation of double-strand breaks (Gaillard et al. 2015). Results from the current study clearly reveal that BPDE treatment in nanomolar concentrations induces replication stress during S phase (Fig. 6). Furthermore, we provide strong evidence that PARP1 is a key factor to overcome BPDE-induced replication stress (Fig. 7). The initial induction of $\gamma \mathrm{H} 2 \mathrm{~A}$.X upon BPDE treatment was comparable between PARP1 proficient and deficient S-phase cells, implying induction of equal amounts of replication damage. However, over time ( $\geq 8 \mathrm{~h})$, PARPl KO cells showed strongly increased levels of phosphorylated H2A.X compared to wild-type cells (Fig. 6a). Thus, it can be hypothesized that PARPI proficient cells readily counteract the induced replication stress, prevented strand breakage, or efficiently repaired collapsed forks. PARP1 KO cells, however, accumulated more collapsed replication forks and DSBs, as evident by the strong increase of 53BP1/yH2A.X, and were less capable to timely repair these by HR. Such a model is supported by the long-lasting low-level increase in PAR formation over several hours, since in such unsynchronized 
cultures, cells enter $\mathrm{S}$ phase at different timepoints, leading to constant replication stress in the cell population.

In general, blocked replication forks can be handled in two ways. The damage is either repaired by homologous recombination or bypassed by translesion synthesis polymerases (Gaillard et al. 2015). Both error-free as well as errorprone translesion bypass have been described (Christmann et al. 2016; Li et al. 2002; Temviriyanukul et al. 2012), the latter of which was shown to be at least in part responsible for overall BPDE mutagenicity. Thus, it is well conceivable that the potentiation of BPDE mutagenicity after PARP inhibition (Fig. 8) can be explained by a shift from homologous recombination repair to translesion synthesis. Considering the findings from the current study, it is tempting to speculate that an impaired PARylation response may contribute to an increased risk for $\mathrm{B}[\mathrm{a}] \mathrm{P}-$ induced mutations and tumor formation on the organismic level, e.g., in cigarette smokeinduced lung tumors (Li et al. 2017).

Acknowledgements This work was supported by the German Research Foundation (DFG) through the Konstanz Research School Chemical Biology (KoRSCB) and the Collaborative Research Center (CRC) 969, and the University of Konstanz through the Young Scholar Fund (YSF). This study was enabled by the core facilities for light microscopy (Bioimaging Center, Uni KN) and flow cytometry (FlowKON, Uni KN).

Open Access This article is distributed under the terms of the Creative Commons Attribution 4.0 International License (http://creativecommons.org/licenses/by/4.0/), which permits unrestricted use, distribution, and reproduction in any medium, provided you give appropriate credit to the original author(s) and the source, provide a link to the Creative Commons license, and indicate if changes were made.

\section{References}

Akerman GS, Rosenzweig BA, Domon OE et al (2004) Gene expression profiles and genetic damage in benzo(a)pyrene diol epoxide-exposed TK6 cells. Mutat Res 549(1-2):43-64. https://doi. org/10.1016/j.mrfmmm.2003.11.013

Angerer J, Mannschreck C, Gundel J (1997) Biological monitoring and biochemical effect monitoring of exposure to polycyclic aromatic hydrocarbons. Int Arch Occup Environ Health 70(6):365-377

Benjamin RC, Gill DM (1980) ADP-ribosylation in mammalian cell ghosts. Dependence of poly(ADP-ribose) synthesis on strand breakage in DNA. J Biol Chem 255(21):10493-10501

Berti M, Ray Chaudhuri A, Thangavel S et al (2013) Human RECQ1 promotes restart of replication forks reversed by DNA topoisomerase I inhibition. Nat Struct Mol Biol 20(3):347-354. https://doi. org/10.1038/nsmb.2501

Briede JJ, Godschalk RW, Emans MT et al (2004) In vitro and in vivo studies on oxygen free radical and DNA adduct formation in rat lung and liver during benzo[a]pyrene metabolism. Free Radic Res 38(9):995-1002. https://doi.org/10.1080/10715760400000976

Bryant HE, Petermann E, Schultz N et al (2009) PARP is activated at stalled forks to mediate Mre11-dependent replication restart and recombination. EMBO J 28(17):2601-2615. https://doi. org/10.1038/emboj.2009.206

Burger K, Matt K, Kieser N, Gebhard D, Bergemann J (2010) A modified fluorimetric host cell reactivation assay to determine the repair capacity of primary keratinocytes, melanocytes and fibroblasts. BMC Biotechnol 10:46. https://doi.org/10.1186/1472-6750-10-46

Christmann M, Boisseau C, Kitzinger R et al (2016) Adaptive upregulation of DNA repair genes following benzo(a)pyrene diol epoxide protects against cell death at the expense of mutations. Nucleic Acids Res 44(22):10727-10743. https://doi.org/10.1093/nar/ gkw873

Ciccia A, Elledge SJ (2010) The DNA damage response: making it safe to play with knives. Mol Cell 40(2):179-204. https://doi. org/10.1016/j.molcel.2010.09.019

D'Silva I, Pelletier JD, Lagueux J et al (1999) Relative affinities of poly(ADP-ribose) polymerase and DNA-dependent protein kinase for DNA strand interruptions. Biochim Biophys Acta 1430(1):119-126

Deng Q, Huang S, Zhang X et al (2014) Plasma microRNA expression and micronuclei frequency in workers exposed to polycyclic aromatic hydrocarbons. Environ Health Perspect 122(7):719-725. https://doi.org/10.1289/ehp.1307080

Donauer J, Schreck I, Liebel U, Weiss C (2012) Role and interaction of $\mathrm{p} 53, \mathrm{BAX}$ and the stress-activated protein kinases p38 and JNK in benzo(a)pyrene-diolepoxide induced apoptosis in human colon carcinoma cells. Arch Toxicol 86(2):329-337. https://doi. org/10.1007/s00204-011-0757-3

Dreij K, Seidel A, Jernstrom B (2005) Differential removal of DNA adducts derived from anti-diol epoxides of dibenzo[a,1]pyrene and benzo[a]pyrene in human cells. Chem Res Toxicol 18(4):655-664. https://doi.org/10.1021/tx0497090

EPA US (2006) Benzo(a)pyrene (BaP). https://www.epa.gov/sites/production/files/2014-03/documents/pahs_factsheet_cdc_2013.pdf

Fischer JM, Popp O, Gebhard D et al (2014) Poly(ADP-ribose)-mediated interplay of XPA and PARP1 leads to reciprocal regulation of protein function. FEBS J 281(16):3625-3641. https://doi. org/10.1111/febs. 12885

Fouquerel E, Sobol RW (2014) ARTD1 (PARP1) activation and NAD(+) in DNA repair and cell death. DNA Repair 23:27-32. https://doi.org/10.1016/j.dnarep.2014.09.004

Gaillard H, Garcia-Muse T, Aguilera A (2015) Replication stress and cancer. Nat Rev Cancer 15(5):276-289. https://doi.org/10.1038/ $\operatorname{nrc} 3916$

Gelboin HV (1980) Benzo[alpha]pyrene metabolism, activation and carcinogenesis: role and regulation of mixed-function oxidases and related enzymes. Physiol Rev 60(4):1107-1166

Haince JF, McDonald D, Rodrigue A et al (2008) PARP1-dependent kinetics of recruitment of MRE11 and NBS1 proteins to multiple DNA damage sites. J Biol Chem 283(2):1197-2208

Hottiger MO (2015) Nuclear ADP-Ribosylation and its role in chromatin plasticity, cell differentiation, and epigenetics. Ann Rev Biochem. https://doi.org/10.1146/annurev-biochem-060614-034506

Jacobson EL, Jacobson MK (1976) Pyridine nucleotide levels as a function of growth in normal and transformed 3T3 cells. Arch Biochem Biophys 175(2):627-634

Kim JH, Stansbury KH, Walker NJ, Trush MA, Strickland PT, Sutter TR (1998) Metabolism of benzo[a]pyrene and benzo[a]pyrene-7,8-diol by human cytochrome P450 1B1. Carcinogenesis 19(10):1847-1853

Kim KH, Jahan SA, Kabir E, Brown RJ (2013) A review of airborne polycyclic aromatic hydrocarbons (PAHs) and their human health effects. Environ Int 60:71-80. https://doi.org/10.1016/j. envint.2013.07.019

King BS, Cooper KL, Liu KJ, Hudson LG (2012) Poly(ADP-ribose) contributes to an association between poly(ADP-ribose) polymerase- 1 and xeroderma pigmentosum complementation group $\mathrm{A}$ in nucleotide excision repair. J Biol Chem 287(47):39824-39833. https://doi.org/10.1074/jbc.M112.393504

Lee YC, Cai Y, Mu H et al (2014) The relationships between XPC binding to conformationally diverse DNA adducts and their 
excision by the human NER system: is there a correlation? DNA Repair 19:55-63. https://doi.org/10.1016/j.dnarep.2014.03.026

Li Z, Zhang H, McManus TP, McCormick JJ, Lawrence CW, Maher VM (2002) hREV3 is essential for error-prone translesion synthesis past UV or benzo[a]pyrene diol epoxide-induced DNA lesions in human fibroblasts. Mutat Res 510(1-2):71-80

Li W, Hu J, Adebali O et al (2017) Human genome-wide repair map of DNA damage caused by the cigarette smoke carcinogen benzo[a]pyrene. Proc Natl Acad Sci. https://doi.org/10.1073/ pnas. 1706021114

Lin T, Yang MS (2008) Benzo[a]pyrene-induced necrosis in the HepG(2) cells via PARP-1 activation and NAD(+) depletion. Toxicology 245(1-2):147-153. https://doi.org/10.1016/j. tox.2007.12.020

Lonskaya I, Potaman VN, Shlyakhtenko LS, Oussatcheva EA, Lyubchenko YL, Soldatenkov VA (2005) Regulation of poly(ADP-ribose) polymerase-1 by DNA structure-specific binding. J Biol Chem 280(17):17076-17083. https://doi.org/10.1074/ jbc.M413483200

Luijsterburg MS, Lindh M, Acs K et al (2012) DDB2 promotes chromatin decondensation at UV-induced DNA damage. J Cell Biol 197(2):267-281. https://doi.org/10.1083/jcb.201106074

Madureira DJ, Weiss FT, Van Midwoud P, Helbling DE, Sturla SJ, Schirmer K (2014) Systems toxicology approach to understand the kinetics of benzo(a)pyrene uptake, biotransformation, and DNA adduct formation in a liver cell model. Chem Res Toxicol 27(3):443-453. https://doi.org/10.1021/tx400446q

Marteijn JA, Lans H, Vermeulen W, Hoeijmakers JH (2014) Understanding nucleotide excision repair and its roles in cancer and ageing. Nat Rev Mol Cell Biol 15(7):465-481. https://doi. org/10.1038/nrm3822

Martello R, Mangerich A, Sass S, Dedon PC, Burkle A (2013) Quantification of cellular poly(ADP-ribosyl)ation by stable isotope dilution mass spectrometry reveals tissue- and drug-dependent stress response dynamics. ACS Chem Biol 8(7):1567-1575. https://doi. org/10.1021/cb400170b

Moserova M, Kotrbova V, Aimova D, Sulc M, Frei E, Stiborova M (2009) Analysis of benzo[a]pyrene metabolites formed by rat hepatic microsomes using high pressure liquid chromatography: optimization of the method. Interdiscip Toxicol 2(4):239-244. https://doi.org/10.2478/v10102-009-0024-0

Newbold RF, Brookes P (1976) Exceptional mutagenicity of a benzo[a]pyrene diol epoxide in cultured mammalian cells. Nature 261(5555):52-54

Panier S, Boulton SJ (2014) Double-strand break repair: 53BP1 comes into focus. Nat Rev Mol Cell Biol 15(1):7-18. https://doi. org/10.1038/nrm3719

Paules RS, Cordeiro-Stone M, Mass MJ, Poirier MC, Yuspa SH, Kaufman DG (1988) Benzo[alpha]pyrene diol epoxide I binds to DNA at replication forks. Proc Natl Acad Sci USA 85(7):2176-2180

Pavanello S, Kapka L, Siwinska E, Mielzynska D, Bolognesi C, Clonfero E (2008) Micronuclei related to anti-B[a]PDE-DNA adduct in peripheral blood lymphocytes of heavily polycyclic aromatic hydrocarbon-exposed nonsmoking coke-oven workers and controls. Cancer epidemiology, biomarkers \& prevention : a publication of the American Association for Cancer Research. Cospons Am Soc Preven Oncol 17(10):2795-2799. https://doi. org/10.1158/1055-9965.EPI-08-0346

Piberger AL, Krüger CT, Strauch BM, Schneider B, Hartwig A (2017) BPDE-induced genotoxicity: relationship between DNA adducts, mutagenicity in the in vitro PIG-A assay, and the transcriptional response to DNA damage in TK6 cells. Arch Toxicol. https://doi. org/10.1007/s00204-017-2003-0

Pines A, Vrouwe MG, Marteijn JA et al (2012) PARP1 promotes nucleotide excision repair through DDB2 stabilization and recruitment of ALC1. J Cell Biol 199(2):235-249. https://doi.org/10.1083/ jcb.201112132

Pion E, Ullmann GM, Ame JC, Gerard D, de Murcia G, Bombarda E (2005) DNA-induced dimerization of poly(ADP-ribose) polymerase-1 triggers its activation. Biochemistry 44(44):14670-14681. https://doi.org/10.1021/bi050755o

Posavec Marjanovic M, Crawford K, Ahel I (2016) PARP, transcription and chromatin modeling. Semin Cell Dev Biol. https://doi. org/10.1016/j.semcdb.2016.09.014

Purohit NK, Robu M, Shah RG, Geacintov NE, Shah GM (2016) Characterization of the interactions of PARP-1 with UV-damaged DNA in vivo and in vitro. Sci Rep 6:19020. https://doi. org/10.1038/srep19020

Rank L, Veith S, Gwosch EC et al (2016) Analyzing structure-function relationships of artificial and cancer-associated PARP1 variants by reconstituting TALEN-generated HeLa PARP1 knock-out cells. Nucleic Acids Res 44(21):10386-10405. https://doi.org/10.1093/ nar/gkw859

Ray Chaudhuri A, Nussenzweig A (2017) The multifaceted roles of PARP1 in DNA repair and chromatin remodelling. Nat Rev Mol Cell Biol. https://doi.org/10.1038/nrm.2017.53

Ray Chaudhuri A, Hashimoto Y, Herrador R et al (2012) Topoisomerase I poisoning results in PARP-mediated replication fork reversal. Nat Struct Mol Biol 19(4):417-423. https://doi.org/10.1038/ nsmb. 2258

Robu M, Shah RG, Petitclerc N, Brind'Amour J, Kandan-Kulangara F, Shah GM (2013) Role of poly(ADP-ribose) polymerase-1 in the removal of UV-induced DNA lesions by nucleotide excision repair. Proc Natl Acad Sci USA 110(5):1658-1663. https://doi. org/10.1073/pnas. 1209507110

Robu M, Shah RG, Purohit NK, Zhou P, Naegeli H, Shah GM (2017) Poly(ADP-ribose) polymerase 1 escorts XPC to UV-induced DNA lesions during nucleotide excision repair. Proc Natl Acad Sci USA. https://doi.org/10.1073/pnas.1706981114

Rothkamm K, Barnard S, Moquet J, Ellender M, Rana Z, BurdakRothkamm S (2015) DNA damage foci: meaning and significance. Environ Mol Mutagenes 56(6):491-504. https://doi.org/10.1002/ em. 21944

Scharer OD (2013) Nucleotide excision repair in eukaryotes. Cold Spring Harbor Perspect Biol 5(10):a012609. https://doi. org/10.1101/cshperspect.a012609

Scheibye-Knudsen M, Mitchell SJ, Fang EF et al (2014) A high-fat diet and $\mathrm{NAD}(+)$ activate Sirt1 to rescue premature aging in cockayne syndrome. Cell Metabol 20(5):840-855. https://doi.org/10.1016/j. cmet.2014.10.005

Scrima A, Konickova R, Czyzewski BK et al (2008) Structural basis of UV DNA-damage recognition by the DDB1-DDB2 complex. Cell 135(7):1213-1223. https://doi.org/10.1016/j.cell.2008.10.045

Scully R, Xie A (2013) Double strand break repair functions of histone H2AX. Mutat Res 750(1-2):5-14. https://doi.org/10.1016/j. mrfmmm.2013.07.007

Spivak G (2015) Nucleotide excision repair in humans. DNA Repair 36:13-18. https://doi.org/10.1016/j.dnarep.2015.09.003

Szilard RK, Jacques P-E, Laramee L et al (2010) Systematic identification of fragile sites via genome-wide location analysis of [gamma]-H2AX. Nat Struct Mol Biol 17(3):299-305

Tao GH, Yang LQ, Gong CM et al (2009) Effect of PARP-1 deficiency on DNA damage and repair in human bronchial epithelial cells exposed to Benzo(a)pyrene. Mol Biol Rep 36(8):2413-2422. https://doi.org/10.1007/s11033-009-9472-z

Temviriyanukul P, Meijers M, van Hees-Stuivenberg S et al (2012) Different sets of translesion synthesis DNA polymerases protect from genome instability induced by distinct food-derived genotoxins. Toxicol Sci Off J Soc Toxicol 127(1):130-138. https://doi. org/10.1093/toxsci/kfs074 
Thorslund T, von Kobbe C, Harrigan JA et al (2005) Cooperation of the Cockayne syndrome group B protein and poly(ADPribose) polymerase 1 in the response to oxidative stress. Mol Cell Biol 25(17):7625-7636. https://doi.org/10.1128/ MCB.25.17.7625-7636.2005

Ueda K, Hayaishi O (1985) ADP-ribosylation. Ann Rev Biochem 54:73-100. https://doi.org/10.1146/annurev.bi.54.070185.000445

Vodenicharov MD, Ghodgaonkar MM, Halappanavar SS, Shah RG, Shah GM (2005) Mechanism of early biphasic activation of poly(ADP-ribose) polymerase-1 in response to ultraviolet B radiation. J Cell Sci 118(Pt 3):589-599. https://doi.org/10.1242/ jes.01636
Wani MA, Zhu Q, El-Mahdy M, Venkatachalam S, Wani AA (2000) Enhanced sensitivity to anti-benzo(a)pyrene-diol-epoxide DNA damage correlates with decreased global genomic repair attributable to abrogated p53 function in human cells. Cancer Res 60(8):2273-2280

Wood RD (1999) DNA damage recognition during nucleotide excision repair in mammalian cells. Biochimie 81(1-2):39-44

Zubel T, Martello R, Burkle A, Mangerich A (2017) Quantitation of Poly(ADP-Ribose) by Isotope Dilution Mass Spectrometry. Methods in molecular biology. (Clifton NJ) 1608:3-18. https:// doi.org/10.1007/978-1-4939-6993-7_1 